\title{
Completion of the ATR LEU Conversion Conceptual Design
}

\section{Thomas Maddock, Joe Palmer}

\author{
March 2018
}

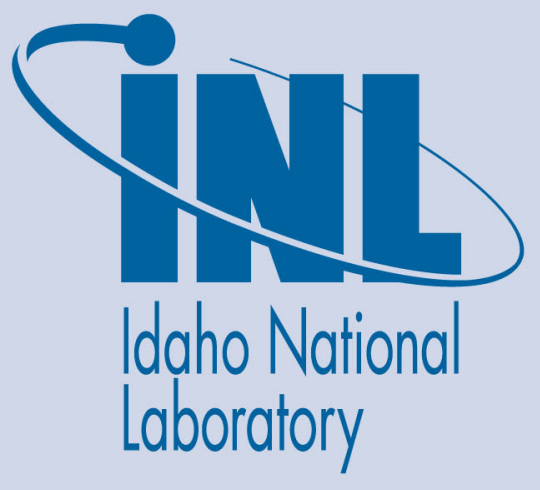

The INL is a U.S. Department of Energy National Laboratory operated by Battelle Energy Alliance 


\section{DISCLAIMER}

This information was prepared as an account of work sponsored by an agency of the U.S. Government. Neither the U.S. Government nor any agency thereof, nor any of their employees, makes any warranty, expressed or implied, or assumes any legal liability or responsibility for the accuracy, completeness, or usefulness, of any information, apparatus, product, or process disclosed, or represents that its use would not infringe privately owned rights. References herein to any specific commercial product, process, or service by trade name, trade mark, manufacturer, or otherwise, does not necessarily constitute or imply its endorsement, recommendation, or favoring by the U.S. Government or any agency thereof. The views and opinions of authors expressed herein do not necessarily state or reflect those of the U.S. Government or any agency thereof. 
INL/EXT-18-50114

Revision 0

\section{Completion of the ATR LEU Conversion Conceptual Design}

Thomas Maddock, Joe Palmer

March 2018

Idaho National Laboratory Idaho Falls, Idaho 83415

http://www.inl.gov

Prepared for the

U.S. Department of Energy

Under DOE Idaho Operations Office

Contract DE-AC07-05ID14517 



\title{
Completion of the ATR LEU Conversion Conceptual Design
}

\author{
INL/EXT-18-50114 \\ Revision 0
}

March 2018

\section{Approved by:}

See eCR 657514

Eric Woolstenhulme

Date

ATR LEU Conversion Project Manager

See eCR 657514

Thomas Maddock

Date

ATR LEU Conversion Technical Lead

See eCR 657514

Joe Palmer

Design Review Chairman

Date

See eCR 657514

Anne McCartin

Date 


\section{SUMMARY}

The Advanced Test Reactor (ATR) Low Enriched Uranium (LEU) Conversion Project at the Idaho National Laboratory (INL) has been developing a new fuel element design capable of converting the ATR from Highly Enriched Uranium (HEU) to LEU fuel. A single concept was selected and analyzed in a series of reports. On October 26, 2017 a Conceptual Design Review kickoff meeting was held. Reviewers took the next two weeks to document their comments on the design and analysis. Those comments have been resolved to the satisfaction of the reviewers. Not all of the known issues and short comings of the design have been resolved. Some may never be resolved but mitigation strategies are being developed that should reduce the impact to acceptable levels. It is recommended that the current design be approved by the U.S. High Performance Research Reactor (HPRR) Program for fabrication and used for the ET-1 base fuel qualification test. It is also recommended that analysis for the conversion of ATR and ATR Critical reactors and the necessary Safety Analysis Report (SAR) addendums for the testing of the ATR LEU elements proceed using the current design. Where there are remaining ambiguities in the design specifications or drawings, it is recommended that they be clarified with revisions or superseding documentation. 


\section{CONTENTS}

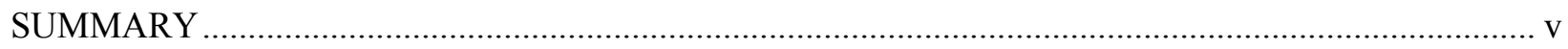

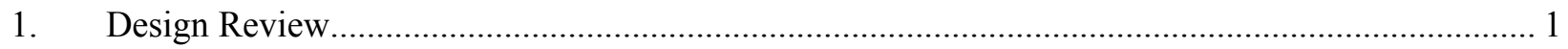

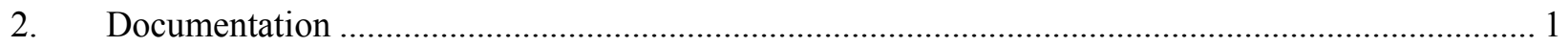

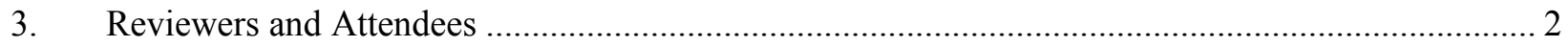

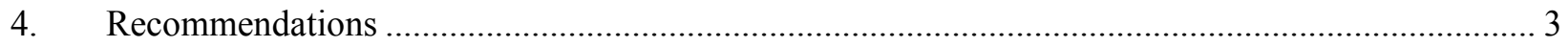

Appendix A Attendance Sheet .............................................................................................

Appendix B Comment Review Sheets ................................................................................ 6

TABLES

Table 1. Conceptual Design Documents Subject to Review.................................................................. 1

Table 2. Attendees at the Conceptual Design Review........................................................................ 2 


\section{Completion of the ATR LEU Conversion Conceptual Design}

\section{Design Review}

In accordance with PLN-5391, "Conceptual Design Plan for the ATR LEU Conversion Element," a conceptual design was developed for a new element to convert the ATR to LEU fuel. During development work, the fuel element was designated Mark 1A Enhanced LEU Fuel (Mark 1A ELF). PLN5391 outlined a series of four hypothetical ATR cycles that would be analyzed to determine if "the fuel design has a high probability of meeting the ATR operational and safety objectives." The analysis of those cycles is complete, and the conceptual design review has been held.

The review period was initiated with a kick-off meeting held October 26, 2017. The design review package (Table 1) was presented and reviewer responsibilities and expectations discussed. Presentations by the project team included a project overview and summaries of the neutronic, thermal, and structural analyses. The participants were instructed to review the design in accordance with their knowledge area and submit written comments, questions, or deficiencies (CQDs). The CQDs were received from reviewers on Form 412.13. Their comments were resolved and acceptance signatures were received. The 412.13 forms are attached in Appendix B.

\section{Documentation}

The documents shown in Table 1 were provided to the reviewers. All documents were released or in a final draft form having been technically checked previous to the review. All of the ATR LEU Conversion Project's conceptual design work was done at quality level 3. Independent peer reviews are not required at the INL for quality level 3 work, but were performed regardless because of the importance of the conceptual design. When the final design phase begins, all documents used to support the development of a SAR addendum or a SAR revision will be performed as Safety Structure System or Component (SSC) applicable. Recent changes to INL procedures created the Safety SSC applicable designation for Engineering Calculation and Analysis Reports (ECARs), which is similar to quality level 1 in the old procedures. Regardless of the terminology, work done to support a nuclear facility's safety basis will be performed with the highest level of rigor, whereas conceptual work was done to a lower level of rigor.

An additional conceptual document is being created to supersede TEV-1972, "Conceptual Design Parameters for ATR LEU U-MO Conversion Demonstration Experimental Irradiations." The new document was not subject to the design review and is also quality level 3. It has been created at the request of the U.S. HPRR Program Fuel Qualification pillar to provide expected ATR fuel plate power, flux, and burnup information, as opposed to conservative or bounding values presented in other conceptual design documents. This document supports the design of future irradiation tests and will be provided to the Reactor Conversion pillar lead to share with the other pillars upon completion.

Table 1. Conceptual Design Documents Subject to Review.

\begin{tabular}{|l|l|}
\hline Document Identifier & Document Title \\
\hline ECAR-3908 & Serpent Model Used in ELF Mk 1A Conceptual Design Neutronic Analysis \\
\hline ECAR-3909 & Results of ELF Mk 1A Conceptual Design Neutronic Analysis \\
\hline ECAR-3162 Rev 0 & ELF Concept Structural Evaluation for ATR Vessel Loadings \\
\hline DWG-604400 Rev 0 & ATR Mark 1A ELF Fuel Element Drawing \\
\hline SPC-1694 Rev 0 & ATR Mark 1A ELF Fuel Specification \\
\hline
\end{tabular}




\begin{tabular}{|l|l|}
\hline 1129-0076-CALC-002 & ATR LEU Cycle R1 Analysis \\
\hline 1129-0076-CALC-003 & Mark 1A ELF Thermal Hydraulic Inputs \\
\hline 1129-0076-CALC-006 & ATR LEU Cycle R2 Analysis \\
\hline
\end{tabular}

\section{Reviewers and Attendees}

Three mandatory reviewers were selected by the ATR Conversion project to review work in their fields of expertise. Hikaru Hiruta reviewed the neutronic ECARs. Nolan Anderson reviewed the thermal/hydraulic Calculation Reports (CALCs), and Nate Oldham reviewed the fuel element drawings and structural ECARs. All others who attended the conceptual design review kickoff meeting were invited to review the documents and provide comments if they desired.

Table 2 is a list of attendees at the design review kickoff meeting. It also shows who submitted a written comment sheet. The attendance sheet is attached as Appendix A. All of the comment sheets are included in Appendix B.

Table 2. Attendees at the Conceptual Design Review.

\begin{tabular}{|l|l|l|}
\hline Name & Organization & Review Status \\
\hline Gable Roth & INL & \\
\hline Charles Maggart & DOE-NE & \\
\hline Andrew Keene & MPR & \\
\hline Brian Hallee & MPR & \\
\hline Mary Rose Holtz & INL & Comments Received \\
\hline Boyd Christensen & INL & \\
\hline Zain Karriem & INL & Comments Received \\
\hline Jeff Brower & INL & Mandatory Reviewer - Thermal/Hydraulic \\
\hline Nolan Anderson & INL & Mandatory Reviewer - Neutronic \\
\hline Hikaru Hiruta & INL & \\
\hline Adam Robinson & INL & \\
\hline Vern M Peterson & DOE-ID & \\
\hline Ryan Little & INL & \\
\hline Aleksey Rezvoi & INL & \\
\hline Vic Pearson & DOE & \\
\hline Evan Nef & INL & \\
\hline Eric Woolstenhulme & INL & \\
\hline Thad Heltemes & ANL & \\
\hline Nick Woolstenhulme & INL & \\
\hline Barry Rabin & INL & \\
\hline Erik Wilson & ANL & Comments Received \\
\hline Tom Maddock & INL & \\
\hline Jody Henley & INL & \\
\hline Anne McCartin & & \\
\hline
\end{tabular}




\begin{tabular}{|l|l|l|}
\hline Nate Oldham & INL & Mandatory Reviewer - Mechanical \\
\hline Demetrius Siachames & MPR & \\
\hline John Stillman & ANL & $\begin{array}{l}\text { Did not attend kickoff meeting but compiled and } \\
\text { submitted all ANL comments }\end{array}$ \\
\hline Jeff Sherman & INL & Comments Received \\
\hline Joe Palmer & INL & Design Review Chairman \\
\hline
\end{tabular}

\section{Recommendations}

1. The ATR LEU Conversion Project has spent many years performing scoping studies and conceptual work. The final set of conceptual design documents subject to this review has shown the design is mature enough to move beyond the conceptual phase. The project recognizes that there are still outstanding questions and issues that need to be resolved. The conceptual analysis provides a high level of confidence that the remaining issues can be overcome using the current conceptual design as the basis. The details of those solutions will need to be determined in the final design and will require element testing.

2. It is recommended that the final design process for the ATR conversion begin immediately. The most notable change in the transition from conceptual to final design will be the types of documents created and their quality level. Final design documents will be performed as safety SSC applicable to support element testing in the ATR which will require safety basis changes. Those changes will come in the form of SAR addendums and revisions.

3. The element drawing and fuel specification were acceptable for a conceptual design, but lacked some of the detail required for final design and fabrication. The element drawings should be redrawn using 3D parametric design software. A revised drawing and fuel specification should be released and sent to the U. S. HPRR Fuel Fabrication pillar to confirm that minor changes or clarifications do not affect the ability to fabricate the fuel elements. The 3D model should be used to estimate the element mass for future structural calculations. Drawing changes should also be disseminated to the thermal, hydraulic, nuclear, and structural analysts to confirm their models, calculations, reports, and references are correct.

4. It is recommended that with the creation of new fuel element drawings, a new name be given to the ATR LEU fuel element to distinguish the final design work from the conceptual or scoping work done under the titles Mark 1A and ELF. The recommended name is the LOWE element, simply standing for low enriched. The name or acronym used for the fuel element has implications in the SAR. LOWE was selected to avoid confusion with other acronyms and descriptions already in use. If future variations of the new element with different plate loadings are required for ATRC or to minimize Beryllium cracking, a "type" designator could be added i.e. LOWE Type 1 and LOWE Type 2 .

5. Although the drawings for the fuel elements require some refinement, it is recommended that the current element design be approved for fabrication. Very small changes to plate positions and channel gaps are expected as well as clarification on the fuel foil location. There are no expected changes to fuel foil and cladding thickness. The fabrication of fuel plates can begin with no increased risk while the remaining details are worked out. 
Appendix A Attendance Sheet

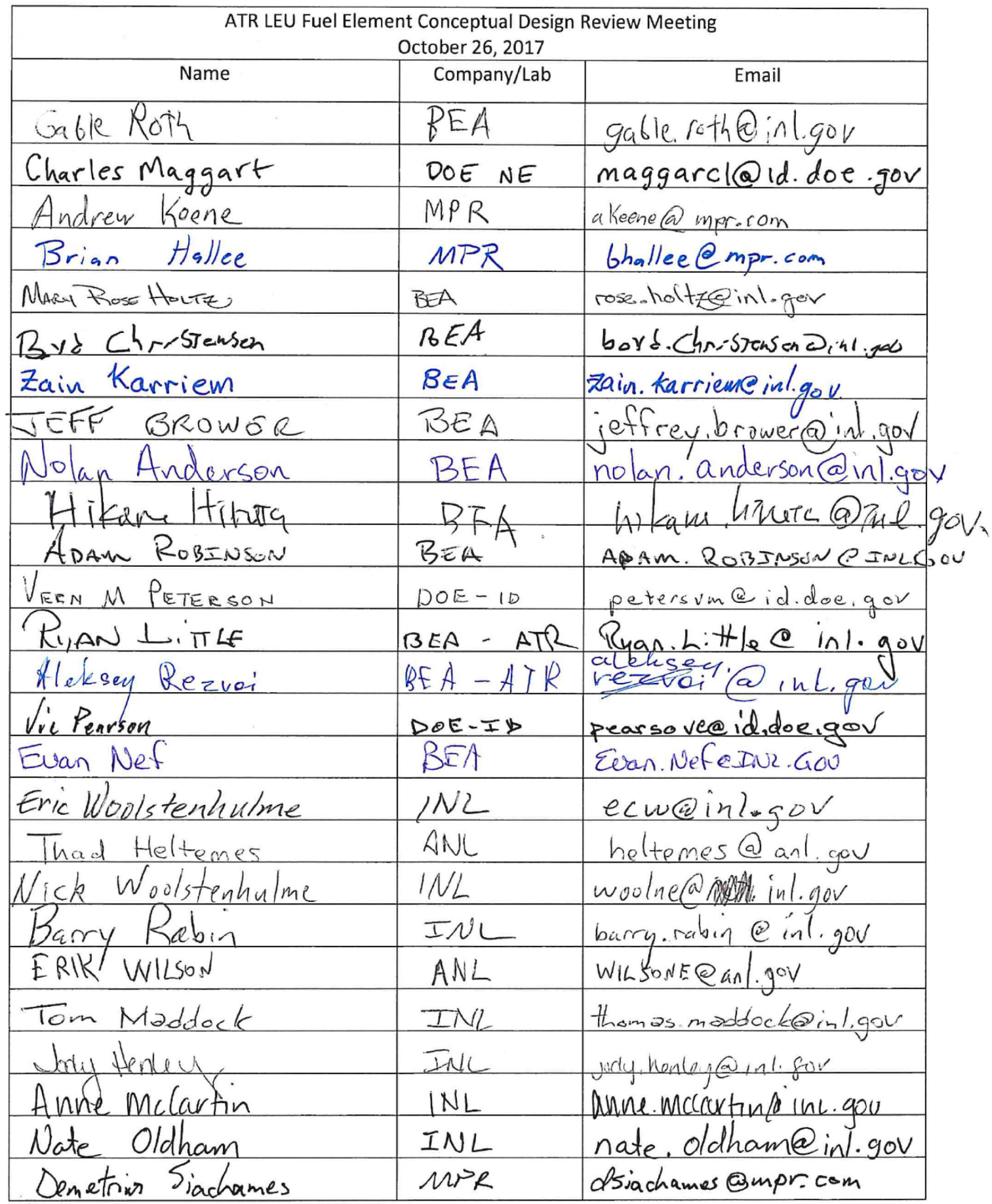

4 


\begin{tabular}{|c|c|c|}
\hline \multicolumn{3}{|c|}{$\begin{array}{l}\text { ATR LEU Fuel Element Conceptual Design Review Meeting } \\
\text { October } 26,2017\end{array}$} \\
\hline Name & Company/Lab & Email \\
\hline Jeff Sherman & $B E A \mid I N L$ & Jeffrey, sherman e inl, gov \\
\hline Joe Palmer & BOAlZNL & vee palmore inl.gor \\
\hline & & \\
\hline & & \\
\hline & & \\
\hline & & \\
\hline & & \\
\hline & & \\
\hline & & \\
\hline & & \\
\hline & & \\
\hline & & \\
\hline & & \\
\hline & & \\
\hline & & \\
\hline & & \\
\hline & & \\
\hline & & \\
\hline . & & \\
\hline & & \\
\hline & & \\
\hline & & \\
\hline & & \\
\hline & & \\
\hline & & \\
\hline & & \\
\hline
\end{tabular}




\section{Appendix B}

\section{Comment Review Sheets}

\begin{tabular}{|c|c|c|c|c|c|c|c|}
\hline $\begin{array}{l}\text { Technical Point of Contact: } \\
\text { MPR }\end{array}$ & Phone No.: & Return Comments To: & MS: & E-Mail: & Comments Due By: & $\begin{array}{l}\text { Reviewer's Name/Discipline: } \\
\text { Anne K. McCartin }\end{array}$ & \begin{tabular}{|l|} 
Phone No.: \\
208-533-4461
\end{tabular} \\
\hline \multicolumn{2}{|l|}{ Comments resolved by: } & \multicolumn{2}{|l|}{ Date: } & \multirow{2}{*}{\multicolumn{3}{|c|}{ 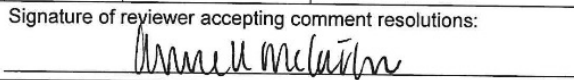 }} & \\
\hline Collin Clark & & $12 / 4 / 2$ & & & & & 912018 \\
\hline
\end{tabular}

comments, submitted within the scope of the review, should be resolved between reviewer and document owner, or their agent. If an acceptable resoltion cannot be negotiated, the reviewer Document ID: 1129-0076-
CALC-006

(teme. Revision ID Revision 1 eCR No: Item No. Page Section or

3.1 and throughout - we should eliminate use of PALM. The use of PALM for a high
power cycle is slang and can be misleading. PALM is only indicative of the hardware

hat cycles a test in and out of the core and the hardware is also fre of the hardware

during lower power cycles. The R2 analysis is not evaluating any cycled experiments, hroughout the document.

we should not be referring to it as a PALM. 


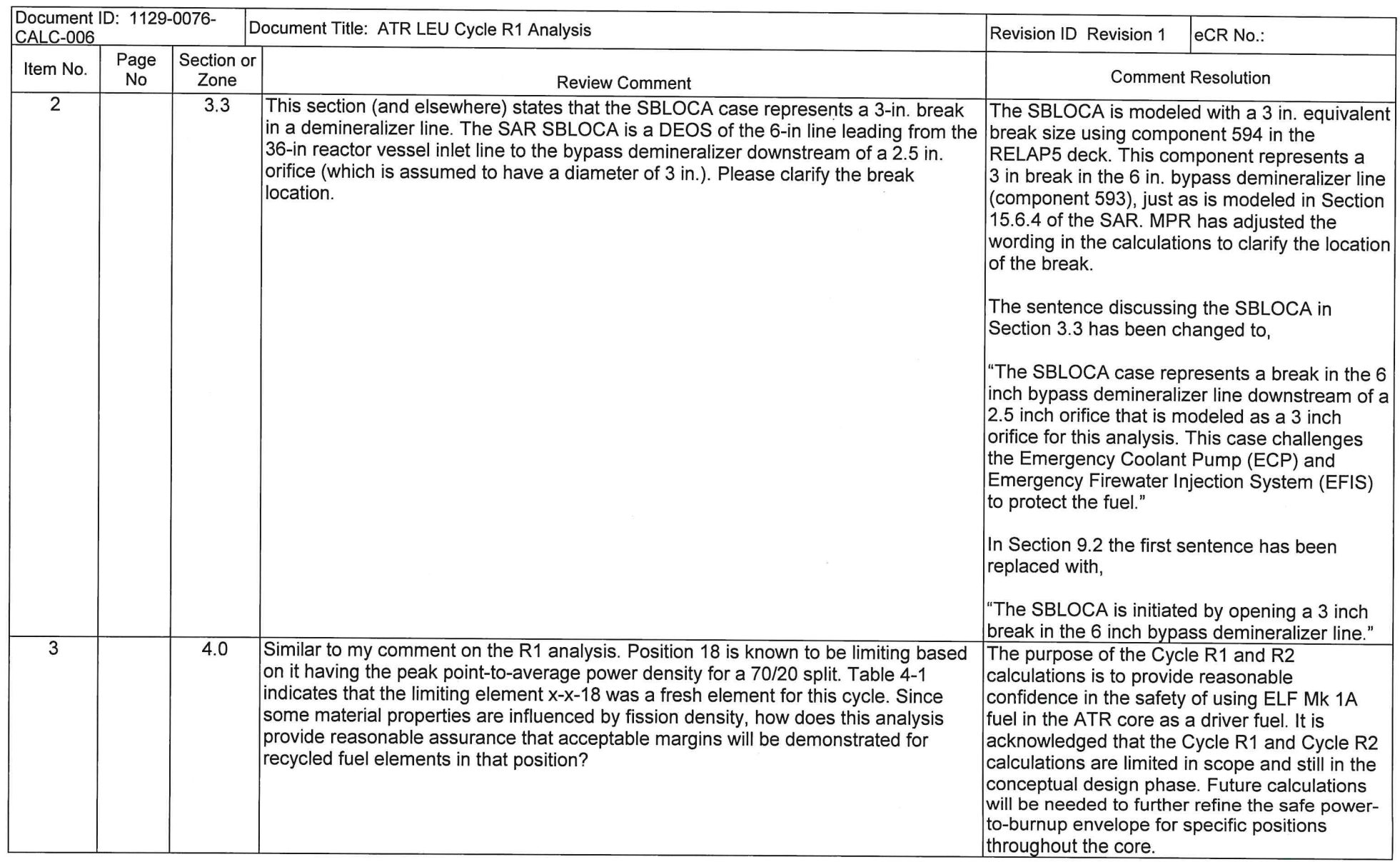




\begin{tabular}{|c|c|c|c|c|}
\hline \multicolumn{3}{|c|}{$\begin{array}{l}\text { Document ID: 1129-0076- } \\
\text { CALC-006 }\end{array}$} & Document Title: ATR LEU Cycle R1 Analysis & Revision ID Revision 1 eCR No.: \\
\hline Item No. & $\begin{array}{c}\text { Page } \\
\text { No }\end{array}$ & $\begin{array}{c}\text { Section or } \\
\text { Zone }\end{array}$ & Review Comment & Comment Resolution \\
\hline 4 & & 5.5 & $\begin{array}{l}\text { This discussion needs clarification that these are not the SAR-153 acceptance criteria } \\
\text { but proposed acceptance criteria for LEU fuel. Note - SAR wording for Condition } 2 \\
\text { has changed and is not consistent with what is presented herein. }\end{array}$ & $\begin{array}{l}\text { Added the following sentence to the end of the } \\
\text { first paragraph in Section } 5.5 \text {. } \\
\text { "Due to differences in the LEU fuel design and } \\
\text { analysis methodology, the acceptance criteria } \\
\text { proposed in Table 5-1 are different than the } \\
\text { ATR SAR; however, the acceptance criteria in } \\
\text { Table 5-1 are consistent with the safety basis } \\
\text { and intent of the ATR SAR." } \\
\text { The last sentence of the paragraph describing } \\
\text { a Condition } 2 \text { event has been changed to } \\
\text { reflect the wording found in SAR-153-15-0, } \\
\text { Revision } 25 . \text { This sentence now reads, } \\
\text { "No rupture of the fuel plate cladding is } \\
\text { allowable unless the accident is a fuel failure } \\
\text { which occurs independent of a reactor, PCS, or } \\
\text { canal accident." }\end{array}$ \\
\hline
\end{tabular}




\begin{tabular}{|c|c|c|c|c|}
\hline \begin{tabular}{|l} 
Document \\
CALC-006
\end{tabular} & 112 & $6-$ & Document Title: ATR LEU Cycle R1 Analysis & \begin{tabular}{|l|l} 
Revision ID Revision 1 & eCR No.: \\
\end{tabular} \\
\hline Item No. & $\begin{array}{l}\text { Page } \\
\text { No }\end{array}$ & $\begin{array}{c}\begin{array}{c}\text { Section or } \\
\text { Zone }\end{array} \\
\end{array}$ & $\begin{array}{r}\text { Review Comment } \\
\end{array}$ & Comment Resolution \\
\hline 5 & & 7.1 .2 & $\begin{array}{l}\text { This section should provide some clarification for the reader that these transient } \\
\text { cases are not representative of the Chapter } 15 \text { bounding accident analyses. } \\
\text { Specifically, the steady state conditions for initiation of the transients are specific to } \\
\text { this cycle and not representative of the steady state conditions assumed in Ch } 15 \\
\text { (they are actually higher than assumed in Ch 15). }\end{array}$ & $\begin{array}{l}\text { Based on the multiple comments about the } \\
\text { ATR SAR, the purpose statement (Section 1.0) } \\
\text { of this calculation is adjusted to provide clarity } \\
\text { that this is not a calculation of record for the } \\
\text { ATR SAR. } \\
\text { The following sentence is added to the end of } \\
\text { the first paragraph of Section } 7.1 .2 \text {. } \\
\text { "The transient cases in this calculation are not } \\
\text { intended to represent the bounding accident } \\
\text { transients of the ATR SAR." } \\
\text { Added the following sentence to the end of the } \\
\text { paragraph under Initial Conditions. } \\
\text { "The initial conditions in this calculation are not } \\
\text { intended to represent the initial conditions used } \\
\text { for the accident analyses in the ATR SAR." }\end{array}$ \\
\hline 6 & & 7.1 .5 & $\begin{array}{l}\text { Bullet following Figure 7-14. The analysis cites a SIPT experimental loop power } \\
\text { adjustment to } 694 \mathrm{~kW} \text { per Roth. Question - the Roth analysis assumes } 250 \mathrm{WM} \text { for } \\
\text { the loop MOD3 model and } 179.5 \mathrm{MW} \text { for the core MOD2.5 model. I am not clear on } \\
\text { the interaction between the two models, but if your core model power is } 230 \mathrm{MW} \text {, is } \\
\text { the } 694 \mathrm{~kW} \text { max experiment loop power calculated in Roth still representative of the } \\
\text { max experiment loop power or could the max be higher? }\end{array}$ & $\begin{array}{l}\text { The } 694 \mathrm{~kW} \text { total experiment loop power is } \\
\text { appropriate since it produces an experimental } \\
\text { fission power of } 200 \mathrm{~kW} \text {, which is the } \\
\text { operational limit given for the SIPT in } \\
\text { EDF-4520. This assumes that the SIPT model } \\
\text { power distribution is appropriate for an LEU } \\
\text { core and for all power tilts, which are both } \\
\text { reasonable assumptions. } \\
\text { An Assumption will be added to the } \\
\text { Calculations that states, "The power distribution } \\
\text { of the SIPT is assumed to be unchanged due to } \\
\text { LEU fuel or due to the modeled core power tilt. } \\
\text { These are reasonable assumptions since the } \\
\text { SIPT power distribution is primarily an axial } \\
\text { distribution, which is very similar for LEU and } \\
\text { HEU fuel, and for different core power tilts." }\end{array}$ \\
\hline
\end{tabular}




\begin{tabular}{|c|c|c|l|l|l|l|}
\hline \multicolumn{2}{|l|}{$\begin{array}{l}\text { Document ID: 1129-0076- } \\
\text { CALC-006 }\end{array}$} & \multicolumn{1}{|l|}{ Document Title: ATR LEU Cycle R1 Analysis } & Review Comment \\
\hline Item No. & $\begin{array}{c}\text { Page } \\
\text { No }\end{array}$ & $\begin{array}{c}\text { Section or } \\
\text { Zone }\end{array}$ & & $\begin{array}{l}\text { Revion ID Revision } 1 \\
\text { eCR No.: }\end{array}$ \\
\hline 7 & & 8.0 & $\begin{array}{l}\text { The paragraph discussing use of ATR-SINDA on bechler should include } \\
\text { acknowledgement that use on bechler has not been qualified under the INL QA } \\
\text { program at the time of this calculation's signing (similar to what was identified for } \\
\text { SASQUATCH). }\end{array}$ & $\begin{array}{l}\text { Added the following sentence to the end of the } \\
\text { paragraph discussing ATR-SINDA. } \\
\text { "This program is undergoing qualification under } \\
\text { InL's QA program for use on bechler at the } \\
\text { time of this calculation's signing." }\end{array}$ \\
\hline 8 & & 9.2 .1 & $\begin{array}{l}\text { Editorial. First sentence should read "sequence of events..." Same comment for 9.3.1. } \\
\text { and 9.4.1. }\end{array}$ & Fixed. \\
\hline 9 & 10.0 & $\begin{array}{l}\text { Reference 14. Editorial. National is spelled wrong. Also, the GDE is not issued in } \\
\text { EDMS. It either needs issued or should be cited as draft. }\end{array}$ & Fixed. \\
\hline
\end{tabular}




\begin{tabular}{|c|c|c|c|c|c|c|c|}
\hline \begin{tabular}{|l|} 
Technical Point of Contact: \\
MPR
\end{tabular} & Phone No.: & Return Comments To: & MS: & E-Mail: & Comments Due By: & $\begin{array}{l}\text { Reviewer's Name/Discipline: } \\
\text { Anne K. McCartin }\end{array}$ & \begin{tabular}{|l|} 
Phone No.: \\
208-533-4461
\end{tabular} \\
\hline $\begin{array}{l}\text { Comments resolved by: } \\
\text { Raheem Rashid }\end{array}$ & & $\begin{array}{l}\text { Date: } \\
12 / 5 / 2\end{array}$ & & \multicolumn{3}{|c|}{ Signature of reviewer accepting comment resolutions: } & $1 / 9 / 2018$ \\
\hline
\end{tabular}

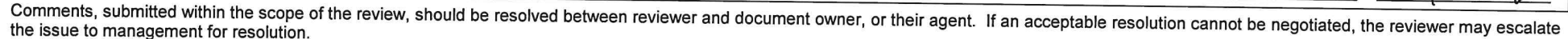

\begin{tabular}{l}
$\begin{array}{l}\text { Document ID: } 1129-0076- \\
\text { CALC-003 R1 }\end{array}$ Document Title: Mark1A ELF Thermal Hydraulic Inputs \\
\hline
\end{tabular}
Item No. Page Section or
Review Comment

Revision ID Revision 1 eCR No.:

Comment Resolution

\begin{tabular}{|c|c|c|c|c|}
\hline & No & Zone & Review Comment & Comment Resolution \\
\hline 1 & & & $\begin{array}{l}\text { List of References. References } 8 \text { and } 22 \text { are out of date and should reflect the current } \\
\text { versions at time of issue. }\end{array}$ & $\begin{array}{l}\text { Agreed. Reference } 8 \text { has been changed to spc } \\
1635 \text { which contains the fuel plate } \\
\text { specifications referenced. SAR-153 is replaced } \\
\text { with the SINDA-SAMPLE manual in the } \\
\text { reference list to avoid referencing the SAR. } \\
\text { SINDA-SAMPLE Heat Transfer Correlation } \\
\text { Uncertainties citation has also been corrected. }\end{array}$ \\
\hline & & & & \\
\hline & & & & \\
\hline & & & & \\
\hline & & & & \\
\hline & & & & \\
\hline & & & & \\
\hline & & & & \\
\hline & & & & \\
\hline & & & & \\
\hline & & & & \\
\hline & & & & \\
\hline & & & & \\
\hline
\end{tabular}




\begin{tabular}{|l|l|c|l|l|l|l|}
\hline $\begin{array}{l}\text { Technical Point of Contact: } \\
\text { MPR }\end{array}$ & Phone No.: & Return Comments To: & MS: & E-Mail: & Comments Due By: & $\begin{array}{l}\text { Reviewer's Name/Discipline: } \\
\text { Anne K. McCartin }\end{array}$ \\
\hline $\begin{array}{l}\text { Comments resolved by: } \\
\text { Collin Clark }\end{array}$ & Date: & $\begin{array}{l}\text { Phone No.: } \\
208-533-4461\end{array}$ \\
\hline
\end{tabular}

the issue to management for resolution.

\begin{tabular}{|c|c|c|c|c|c|}
\hline \multicolumn{3}{|c|}{$\begin{array}{l}\text { Document ID: 1129-0076- } \\
\text { CALC-002 }\end{array}$} & Document Title: ATR LEU Cycle R1 Analysis & Revision ID Revision 1 & eCR No.: \\
\hline Item No. & $\begin{array}{l}\text { Page } \\
\text { No }\end{array}$ & $\begin{array}{c}\text { Section or } \\
\text { Zone }\end{array}$ & Review Comment & \multicolumn{2}{|c|}{ Comment Resolution } \\
\hline 1 & & 3.2 & $\begin{array}{l}\text { Item } 4 \text { should be reworded to eliminate use of PALM. The use of PALM for a high } \\
\text { power cycle is slang and can be misleading. PALM is only indicative of the hardware } \\
\text { that cycles a test in and out of the core, and the hardware is also frequently used } \\
\text { during lower power cycles. The R2 analysis is not evaluating any cycled experiments, } \\
\text { so we should not be referring to it as a PALM. }\end{array}$ & $\begin{array}{l}\text { The mention of PALM } \\
\text { description of Cycle R2 } \\
\text { The "normal operation" } \\
\text { as the "steady operatio } \\
\text { with the new terminolo } \\
\text { calculation. }\end{array}$ & $\begin{array}{l}\text { s removed from the } \\
\text { case is now referred to } \\
\text { n" case to be consistent } \\
\text { y in the Cycle R2 }\end{array}$ \\
\hline
\end{tabular}




\begin{tabular}{|c|c|c|c|c|}
\hline \multicolumn{3}{|c|}{$\begin{array}{l}\text { Document ID: } 1129-0076- \\
\text { CALC-002 }\end{array}$} & Document Title: ATR LEU Cycle R1 Analysis & \begin{tabular}{|l|l} 
Revision ID Revision 1 & eCR No.: \\
\end{tabular} \\
\hline Item No. & $\begin{array}{c}\text { Page } \\
\text { No }\end{array}$ & \begin{tabular}{|l} 
Section or \\
Zone
\end{tabular} & Review Comment & Comment Resolution \\
\hline 2 & & 3.3 & $\begin{array}{l}\text { This section (and elsewhere) states that the SBLOCA case represents a } 3 \text {-in. break } \\
\text { in a demineralizer line. The SAR SBLOCA is a DEOS of the } 6 \text {-in line leading from the } \\
36 \text {-in reactor vessel inlet line to the bypass demineralizer downstream of a } 2.5 \text { in. } \\
\text { orifice (which is assumed to have a diameter of } 3 \text { in.). Please clarify the break } \\
\text { location. }\end{array}$ & $\begin{array}{l}\text { The SBLOCA is modeled with a } 3 \text { in. equivalent } \\
\text { break size using component } 594 \text { in the } \\
\text { RELAP5 deck. This component represents a } \\
3 \text { in break in the } 6 \text { in. bypass demineralizer line } \\
\text { (component } 593 \text { ), just as is modeled in Section } \\
15.6 .4 \text { of the SAR. MPR has adjusted the } \\
\text { wording in the calculations to clarify the location } \\
\text { of the break. } \\
\text { The sentence discussing the SBLOCA in } \\
\text { Section } 3.3 \text { has been changed to, } \\
\text { "The SBLOCA case represents a break in the } 6 \\
\text { inch bypass demineralizer line downstream of a } \\
2.5 \text { inch orifice that is modeled as a } 3 \text { inch } \\
\text { orifice for this analysis. This case challenges } \\
\text { the Emergency Coolant Pump (ECP) and } \\
\text { Emergency Firewater Injection System (EFIS) } \\
\text { to protect the fuel." } \\
\text { In Section } 9.2 \text { the first sentence has been } \\
\text { replaced with, } \\
\text { "The SBLOCA is initiated by opening a } 3 \text { inch } \\
\text { break in the } 6 \text { inch bypass demineralizer line." }\end{array}$ \\
\hline
\end{tabular}




\begin{tabular}{|c|c|c|c|c|}
\hline \multicolumn{3}{|c|}{$\begin{array}{l}\text { Document ID: 1129-0076- } \\
\text { CALC-002 }\end{array}$} & Document Title: ATR LEU Cycle R1 Analysis & Revision ID Revision 1 \\
\hline Item No. & $\begin{array}{l}\text { Page } \\
\text { No }\end{array}$ & $\begin{array}{c}\text { Section or } \\
\text { Zone }\end{array}$ & Review Comment & Comment Resolution \\
\hline 3 & & 3.6 & $\begin{array}{l}\text { Editorial. Second paragraph. Second sentence is missing an "of". "... because the } \\
\text { combination of its power and fission density..." }\end{array}$ & Corrected during Nolan's review. \\
\hline 4 & & 4.0 & $\begin{array}{l}\text { Position } 23 \text { is known to be limiting based on it having the peak point-to-average } \\
\text { power density for a } 60 / 40 \text { split. Table } 4-1 \text { indicates that the limiting element } x-x-23 \\
\text { was a fresh element for this cycle. Since some material properties are influenced by } \\
\text { fission density, how does this analysis provide reasonable assurance that acceptable } \\
\text { margins will be demonstrated for recycled fuel elements in that position? Figure } 3-1 \\
\text { indicates many once used (and twice) used elements with much higher fission } \\
\text { densities. }\end{array}$ & $\begin{array}{l}\text { The purpose of the Cycle R1 and R2 } \\
\text { calculations is to provide reasonable } \\
\text { confidence in the safety of using ELF Mk } 1 \mathrm{~A} \\
\text { fuel in the ATR core as a driver fuel. It is } \\
\text { acknowledged that the Cycle R1 and Cycle R2 } \\
\text { calculations are limited in scope and still in the } \\
\text { conceptual design phase. Future calculations } \\
\text { will be needed to further refine the safe power- } \\
\text { to-burnup envelope for specific positions } \\
\text { throughout the core. }\end{array}$ \\
\hline 5 & & 5.5 & $\begin{array}{l}\text { This discussion needs clarification that these are not the SAR-153 acceptance criteria } \\
\text { but proposed acceptance criteria for LEU fuel. Note - SAR wording for Condition } 2 \\
\text { has changed and is not consistent with what is presented herein. }\end{array}$ & $\begin{array}{l}\text { Added the following sentence to the end of the } \\
\text { first paragraph in Section } 5.5 \text {. } \\
\text { "Due to differences in the LEU fuel design and } \\
\text { analysis methodology, the acceptance criteria } \\
\text { proposed in Table 5-1 are different than the } \\
\text { ATR SAR; however, the acceptance criteria in } \\
\text { Table 5-1 are consistent with the safety basis } \\
\text { and intent of the ATR SAR." } \\
\text { The last sentence of the paragraph describing } \\
\text { a Condition } 2 \text { event has been changed to } \\
\text { reflect the wording found in SAR-153-15-0, } \\
\text { Revision } 25 \text {. This sentence now reads, } \\
\text { "No rupture of the fuel plate cladding is } \\
\text { allowable unless the accident is a fuel failure } \\
\text { which occurs independent of a reactor, PCS, or } \\
\text { canal accident." }\end{array}$ \\
\hline
\end{tabular}




\begin{tabular}{|c|c|c|c|c|}
\hline \multicolumn{3}{|c|}{$\begin{array}{l}\text { Document ID: } 1129-0076- \\
\text { CALC-002 }\end{array}$} & Document Title: ATR LEU Cycle R1 Analysis & Revision ID Revision 1 eCR No.: \\
\hline Item No. & $\begin{array}{l}\text { Page } \\
\text { No }\end{array}$ & $\begin{array}{c}\text { Section or } \\
\text { Zone }\end{array}$ & Review Comment & Comment Resolution \\
\hline 6 & & 7.1 .2 & $\begin{array}{l}\text { This section should provide some clarification for the reader that these transient } \\
\text { cases are not representative of the Chapter } 15 \text { bounding accident analyses. } \\
\text { Specifically, the steady state conditions for initiation of the transients are specific to } \\
\text { this cycle and not representative of the steady state conditions assumed in Ch } 15 \text {, } \\
\text { and the scaling of the loop power for the LOCP is also cycle-specific. }\end{array}$ & $\begin{array}{l}\text { Based on the multiple comments about the } \\
\text { ATR SAR, the purpose statement (Section 1.0) } \\
\text { of this calculation is adjusted to provide clarity } \\
\text { that this is not a calculation of record for the } \\
\text { ATR SAR. } \\
\text { Added the following sentence to the end of the } \\
\text { first paragraph of Section 7.1.2. } \\
\text { "The transient cases in this calculation are not } \\
\text { intended to represent the bounding accident } \\
\text { transients of the ATR SAR." } \\
\text { Added the following sentence to the end of the } \\
\text { paragraph under Initial Conditions. } \\
\text { "The initial conditions in this calculation are not } \\
\text { intended to represent the initial conditions used } \\
\text { for the accident analyses in the ATR SAR." } \\
\text { No change is made for the scaling of the loop } \\
\text { power. The second bullet in Initial Conditions in } \\
\text { Section } 7.1 .5 \text { states that the scaled loop power } \\
\text { is cycle specific. }\end{array}$ \\
\hline 7 & 22 & & Editorial. First paragraph under Pump Parameters is missing a period. & Fixed. \\
\hline 8 & & 8.0 & $\begin{array}{l}\text { The paragraph discussing use of ATR-SINDA on bechler should include } \\
\text { acknowledgement that use on bechler has not been qualified under the INL QA } \\
\text { program at the time of this calculation's signing (similar to what was identified for } \\
\text { SASQUATCH). }\end{array}$ & $\begin{array}{l}\text { Added the following sentence to the end of the } \\
\text { paragraph discussing ATR-SINDA. } \\
\text { "This program is undergoing qualification under } \\
\text { INL's QA program for use on bechler at the } \\
\text { time of this calculation's signing." }\end{array}$ \\
\hline 9 & & 9.1 .1 & $\begin{array}{l}\text { Table 9-1. Note 2. Editorial. Delete extraneous "is a" - "... and vessel inlet pressure } \\
\text { are is a constant RELAP5 inputs." }\end{array}$ & Corrected during Nolan's review. \\
\hline 10 & & 9.2 .1 & $\begin{array}{l}\text { Editorial. First sentence should read "sequence of events..." Same comment for 9.3.1 } \\
\text { and 9.4.1. }\end{array}$ & Fixed. \\
\hline
\end{tabular}


DOCUMENT MANAGEMENT REVIEW COMMENTS AND RESOLUTIONS

Tracking No:

\begin{tabular}{|c|c|c|c|c|c|}
\hline \multicolumn{3}{|c|}{$\begin{array}{l}\text { Document ID: 1129-0076- } \\
\text { CALC-002 }\end{array}$} & Document Title: ATR LEU Cycle R1 Analysis & Revision ID Revision 1 & eCR No.: \\
\hline Item No. & $\begin{array}{l}\text { Page } \\
\text { No }\end{array}$ & \begin{tabular}{|l} 
Section or \\
Zone
\end{tabular} & Review Comment & \multicolumn{2}{|c|}{ Comment Resolution } \\
\hline 11 & & 10.0 & $\begin{array}{l}\text { Reference 14. Editorial. National is spelled wrong. Also, the GDE is not issued in } \\
\text { EDMS. It either needs issued or should be cited as draft. }\end{array}$ & Fixed. & \\
\hline & & & & & \\
\hline & & & & & \\
\hline & & & & & \\
\hline & & & & & \\
\hline & & & & & \\
\hline & & & & & \\
\hline & & & & & \\
\hline
\end{tabular}




\begin{tabular}{|l|l|l|l|l|l|}
\hline $\begin{array}{l}\text { Technical Point of Contact: } \\
\text { Boyd Christensen }\end{array}$ & Phone No: & Return Comments To: & MS: & E-Mai: & Comments Due By: Reviewer's Name/Discipline: \\
\hline $\begin{array}{l}\text { Comments resclved by: } \\
\text { Thomas Maddock }\end{array}$ & Date: & Unknown \\
\hline
\end{tabular}

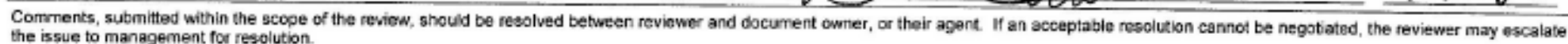

\begin{tabular}{|c|c|c|c|c|}
\hline \multicolumn{3}{|c|}{$\begin{array}{l}\text { Document ID: SPC-1694, } \\
\text { Cacl-002, Calc-003 }\end{array}$} & Document Title: & \multirow{2}{*}{\begin{tabular}{|l|l|} 
Revision ID: & eCR No: \\
& Comment Resolution
\end{tabular}} \\
\hline Item No. & $\begin{array}{c}\text { Page } \\
\text { No }\end{array}$ & \begin{tabular}{|c|}
$\begin{array}{c}\text { Section or } \\
\text { Zone }\end{array}$ \\
\end{tabular} & Review Comment & \\
\hline 1 & 9 of 39 & 1.1 & $\begin{array}{l}\text { SPC-1694, Editorial: In line } 13 \text { of the first para "This document is intended to be } \\
\text { used..." Need to add the word "as" }\end{array}$ & Accepted, the change will be made. \\
\hline 2 & $\begin{array}{c}11 \text { of } \\
39\end{array}$ & 1.3 & $\begin{array}{l}\text { Calc-003, Editorial: In the first two para after Figure 1, be consistent in the use of } \\
\text { "nineteen" curved plates and } 19^{\prime \prime}\end{array}$ & $\begin{array}{l}\text { Do not agree. The word 'nineteen' is not used } \\
\text { in the calculation. }\end{array}$ \\
\hline 3 & & 10.0 & $\begin{array}{l}\text { Calc-002, Spell checkReferences: } 3 \text { (Laboratories to Laboratory), } 14 \text { (Natioanl } \\
\text { Laboratories to National Laboratory), } 19 \text { (Laboratoies to Laboratory) }\end{array}$ & Fixed. \\
\hline 4 & & 7.0 & Calc-003, Spell check Ref 13 (Laboratory, not Laboratories) & $\begin{array}{l}\text { This reference is deleted from the proposed } \\
\text { rev. } 2 \text { version of this calculation to resolve } \\
\text { another review comment for this calculation. }\end{array}$ \\
\hline & & & & \\
\hline & & & & \\
\hline & & & & \\
\hline & & & & \\
\hline & & & & \\
\hline & & & & \\
\hline & & & & \\
\hline & & & & \\
\hline & & & & \\
\hline
\end{tabular}




\begin{tabular}{|c|c|c|c|c|c|c|c|}
\hline Technical Point of Contact: & Phane No:: & Rotum Comments To: & MS: & E-Mait: & Comments Due By: & $\begin{array}{l}\text { Reviewer's Name/Discipline: } \\
\text { Eart Feidman/Thermal-Hydraulics \&. John }\end{array}$ & $\begin{array}{l}\text { Phone No: } \\
630-252-4277\end{array}$ \\
\hline Comments resolved by: & & Date: & & Signa: & oviewar accepting $\infty$ & Sfillman) & \\
\hline
\end{tabular}

Comments, submitto o with in the scope of the revilow, should be resolved botween rewewer and document owner, oc their apent. If an acceptabie resolufion cannot be nagotated, the reviewer may escalate the lssue to maragement for resclution.

\begin{tabular}{|c|c|c|c|c|}
\hline $\begin{array}{l}\text { Document } \\
\text { CALC-CO3 }\end{array}$ & $\begin{array}{l}\text { D: } 1129 \\
\text { Revigion }\end{array}$ & $0076-$ & Document TIte: Nark 1A ELF Thermal Hydraulic Inputs & Revision ID: 1 \\
\hline Item No. & $\begin{array}{c}\text { Page } \\
\mathrm{No}\end{array}$ & $\begin{array}{c}\text { Section or } \\
\text { Zone }\end{array}$ & Review Comment & Comment Resolution \\
\hline 1 & 31 & $\begin{array}{l}\text { Fueled } \\
\text { Width }\end{array}$ & $\begin{array}{l}\text { When the equation for fueled width is evaluated using the fuel plate radi derived from } \\
\text { Section E-E, Sheet 3, of DWG-604400, it does not match the values of the fuel width } \\
\text { reported in Table 4-1 (page 9). }\end{array}$ & $\begin{array}{l}\text { There is a typographical error In the equation, } \\
\text { The widths of the side plate water channels } 2 x \\
0.032^{2} \text { are also subtracted from the fuel } \\
\text { element envelope. } \\
\text { This is accounted for in the fueled widths } \\
\text { reported in Table } 4-1 \text {, so the values are correct. } \\
\text { The equation will be updated to reflect the } \\
\text { contribution of the side plate water channels. } \\
\text { RESPONSE FROM ANL: This issue was } \\
\text { previously identified and addressed as } \\
\text { documented in ANL/RTRTM-17/5, Section } \\
4.3 .4 \text {, where MPR noted that the element } \\
\text { spacing should not be included in the } \\
\text { calculation of the fuel arc width. The radiil in } \\
\text { Section E-E, Sheet 3, DWG-604400 are } \\
\text { relatative to a centroid formed by two lines that } \\
\text { run along the outside edge of the side plates, } \\
\text { and thus exclude the spacing betwoen } \\
\text { elements when they are loaded in the ATR } \\
\text { core. However, while the fuel meat arc widths } \\
\text { reported in Table } 4-1 \text { of the subject report are } \\
\text { calculated with a formula that uses the element } \\
\text { spacing, the analysis appears to be } \\
\text { conservative. We accept the resolution. }\end{array}$ \\
\hline
\end{tabular}




\begin{tabular}{|c|c|c|c|c|}
\hline \multicolumn{3}{|c|}{$\begin{array}{l}\text { Document ID: } 1129-0076- \\
\text { CALC-003, Revision } 1\end{array}$} & Document Title: Mark 1A ELF Thermal Hydraulic Inputs & Revision ID: 1 \\
\hline Item No. & $\begin{array}{l}\text { Page } \\
\text { No }\end{array}$ & $\begin{array}{c}\text { Section or } \\
\text { Zone }\end{array}$ & Review Comment & Comment Resolution \\
\hline 3 & 21 & $\begin{array}{c}\text { Fuel } \\
\text { Blistering } \\
\text { Temp. } \\
\text { Correlatio } \\
n\end{array}$ & $\begin{array}{l}\text { This may be a typographical error. It appears that "Reference } 13 \text { " was inadvertently } \\
\text { substituted for "Reterence 9". }\end{array}$ & $\begin{array}{l}\text { This error has been addressed and corrected in } \\
\text { another review comment and resolution form. } \\
\text { RESPONSE FROM ANL: It is uncertain what } \\
\text { the resolution of this comment is. Nonetheless, } \\
\text { as this is a typographical error, we } \\
\text { acknowledge that the error has been corrected. }\end{array}$ \\
\hline 4 & 20 & $\begin{array}{c}\text { Plate } \\
\text { Swelling } \\
\text { Correlatio } \\
n\end{array}$ & $\begin{array}{l}\text { This may be typographical error. The term "t0" in the denominator should be in the } \\
\text { numerator. As written, the equation evalutes to an incorrect value for the plate } \\
\text { thickness increase due to swelling. }\end{array}$ & $\begin{array}{l}\text { This error has been addressed and corrected in } \\
\text { another review comment and resolution form. } \\
\text { RESPONSE FROM ANL: It is uncertain what } \\
\text { the resolution of this comment is. Nonetheless, } \\
\text { as this is a typographical error, we } \\
\text { acknowledge that the error has been corrected. }\end{array}$ \\
\hline & & & . & \\
\hline & & & & \\
\hline & & & 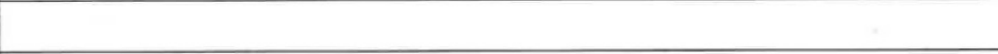 & \\
\hline & & & & \\
\hline & & & & . \\
\hline & & & & \\
\hline & & & & \\
\hline & & & & · \\
\hline & & & & \\
\hline & & & & \\
\hline & & & & \\
\hline & & & & \\
\hline
\end{tabular}




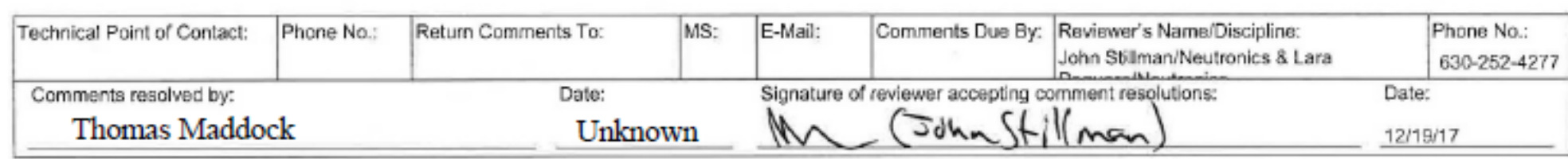

Comments, submittad within the scope of the reviow, should be rasclved between reviewer and document owner, or thair agent. If an acceptable resolution cannot be negotated, the reviguer may escalate the issue to management for resolution.

\begin{tabular}{|c|c|c|c|c|}
\hline \multicolumn{3}{|c|}{ Document ID: OWG-604400 } & Document Title: ATR Enhanced LEU Fuel (ELF) Element Assembly & \multirow{2}{*}{\begin{tabular}{|l|l} 
Revision ID: & eCR No:: \\
& Comment Resolution
\end{tabular}} \\
\hline Item No. & $\begin{array}{c}\text { Page } \\
\text { No }\end{array}$ & $\begin{array}{c}\text { Section or } \\
\text { Zone }\end{array}$ & Review Comment & \\
\hline 1 & 3 & & $\begin{array}{l}\text { The fuel core boundary is drawn with a minimum core boundary that is } 0.570 \text { inches } \\
\text { from the ends of the fuel plate and a maximum core boundary that is } 0.370 \text { inches } \\
\text { from the ends of the fuel plate. The nominal fuel plate length is } 49.5 \text { inches. For the } \\
\text { fuel core to fit within the minimum and maximum core boundaries, the fuel core } \\
\text { length must be between } 48.36 \text { and } 48.76 \text { inches, but the nominal fuel core length for } \\
\text { ATR fuel is } 48.0 \text { inches. }\end{array}$ & $\begin{array}{l}\text { The fuel core boundary and the associated } \\
\text { dimensions and tolerances will be redrawn in a } \\
\text { way that inculdes the nominal value of } 48 \\
\text { inches and maintains the same acceptable } \\
\text { range of } 4 \text { inches on the length. } \\
\text { ANL RESPONSE: We accept the resolution. }\end{array}$ \\
\hline & & & & \\
\hline & & & & \\
\hline & & & & \\
\hline & & & & \\
\hline & & & & \\
\hline & & & & \\
\hline & & & & \\
\hline & & & & \\
\hline & & & & \\
\hline & & & & \\
\hline & & & 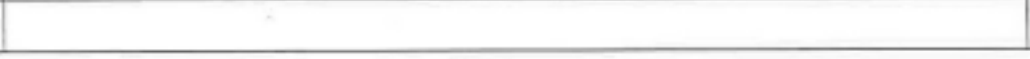 & \\
\hline
\end{tabular}




\begin{tabular}{|c|c|c|c|c|c|c|c|}
\hline Technical Point of Contact: & Fhore Na: & Fioturn Comments To: & MS: & E-Nail: & Comments Due By: & $\begin{array}{l}\text { Reviewar's Name/Discipine: } \\
\text { Eart Feldman/Thamal-Hydraulics \& Jahn }\end{array}$ & $\begin{array}{l}\text { Phane No: } \\
\text { 630-252-4277 }\end{array}$ \\
\hline \multicolumn{2}{|c|}{$\begin{array}{l}\text { Comments resclvod by: } \\
\text { Thomas Maddock }\end{array}$} & \multicolumn{2}{|l|}{ Date: } & \multicolumn{3}{|c|}{ Signature of reviewer accepting cgmment resplutions: } & \\
\hline
\end{tabular}

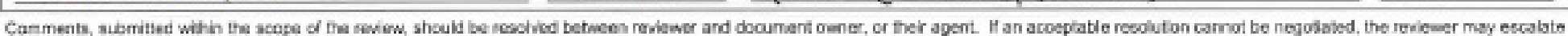
the issue to maragement for reschibion.

\begin{tabular}{|c|c|c|c|c|}
\hline \multicolumn{3}{|c|}{ Document ID: ECAR-3162 } & Document Tite: ELF Concept Structrual Evaluason for ATR Vessed Losdings & \multirow{2}{*}{\begin{tabular}{l|l} 
Revision ID: & OCR Na: \\
& Comment Resolution
\end{tabular}} \\
\hline Item No. & $\begin{array}{c}\text { Page } \\
\text { No }\end{array}$ & $\begin{array}{c}\text { Section or } \\
\text { Zane }\end{array}$ & Ferview Commant & \\
\hline$=$ & & & . & \\
\hline & & & & \\
\hline 1 & 15 & $\begin{array}{c}\text { Candition } \\
4 \text { RIA }\end{array}$ & $\begin{array}{l}\text { This is a typographical error. The second buliet states that the "Greater than } 3 \text {-inch } \\
\text { RIA temperatures..." This should be "Greater then } 0.5 \text {-inch temperatures..." }\end{array}$ & $\begin{array}{l}\text { The typo wil be corrected lo say } 0.5 \text { insteed of } \\
3 \text { inch. } \\
\text { ANL RESPONSE: We accept the resolution. }\end{array}$ \\
\hline & & & & \\
\hline & & & & \\
\hline & & & & \\
\hline & & & & \\
\hline & & & & \\
\hline & & & & \\
\hline & & & & \\
\hline & & & & \\
\hline & & & & \\
\hline & & & & \\
\hline & & & & \\
\hline
\end{tabular}




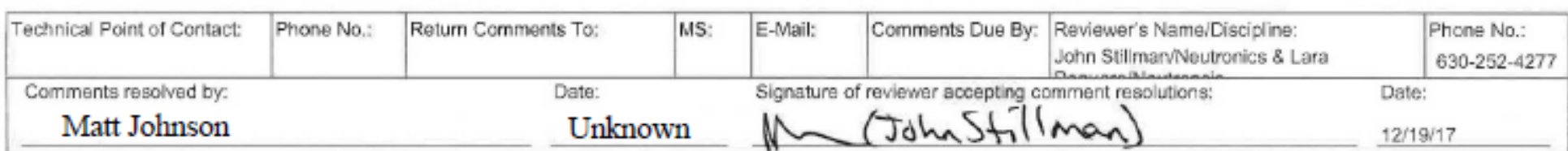

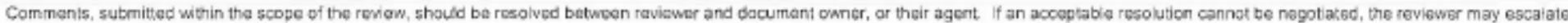
the issue to manegement for reaclution.

\begin{tabular}{|c|c|c|c|c|}
\hline \multicolumn{3}{|c|}{ Document ID: ECAR-3908 } & Document Title: Serpent Model Used in ELF Mk 1 A Conceptual Design Neutronics Analysis & Revision ID: \\
\hline Item No. & $\begin{array}{l}\text { Page } \\
\text { No }\end{array}$ & $\begin{array}{l}\text { Section cr } \\
\text { Zone }\end{array}$ & Review Comment & Comment Resolution \\
\hline 1 & 11 & 8.2 .1 & $\begin{array}{l}\text { Typographical error. It is stated that all coolant channels in the model are } 0.0307 \mathrm{~cm} \\
\text { wide. All coolant channels are modeled as the same width (more commonly, the term } \\
\text { thickness is applied to this dimension). Channels } 1-10 \text { in the ATR element are } 0.078 \\
\text { inches "thick," which converts to } 0.1981 \mathrm{~cm} \text {. Suspect that a units conversion error } \\
\text { was made in reporting the value in the text. }\end{array}$ & $\begin{array}{l}\text { Sentence changed to "All coolant channels are } \\
0.1981 \mathrm{~cm} \text { thick" } \\
\text { ANL RESPONSE: We accept the resolution.. }\end{array}$ \\
\hline
\end{tabular}




\begin{tabular}{|c|c|c|c|c|}
\hline \multicolumn{3}{|c|}{ Document ID: ECAR-3908 } & Document Title: Serpent Model Used in ELF Mk 1A Conceptual Design Neutronics Analysis & Revision ID: \\
\hline Item No. & $\begin{array}{l}\text { Page } \\
\text { No }\end{array}$ & $\begin{array}{c}\text { Section or } \\
\text { Zone }\end{array}$ & Review Comment & Comment Resolution \\
\hline 2 & 11 & Table 2 & $\begin{array}{l}\text { Serpent model may use a fueled width that is narrower than the nominal fuel } \\
\text { dimensions. This is conservative in some respects. For cycle length may be non- } \\
\text { conservative. The as-modeled dimensions for the fuel meat of each plate is given. } \\
\text { Using the arc length and avg. radius values specified in Table } 2 \text {, assuming a side } \\
\text { plate width of } 0.187 \text { inches, and the equation for the fueled width provided on page } \\
31 \text { of MPR report } 1129-0076 \text {-CALC-003, the correpsonding unfueled width from the } \\
\text { edge of the fuel meat to the side plate can be calculated. This calculation yields an } \\
\text { unfueled width of } 0.127 \text { inches. This value is within the range of } 0.045 \text { to } 0.145 \\
\text { inches for the unfueled width specified in Section E-E of Sheet } 3 \text { of DWG-604400. } \\
\text { However, it is wider than the nominal unfueled width of } 0.095 \text { inches. }\end{array}$ & 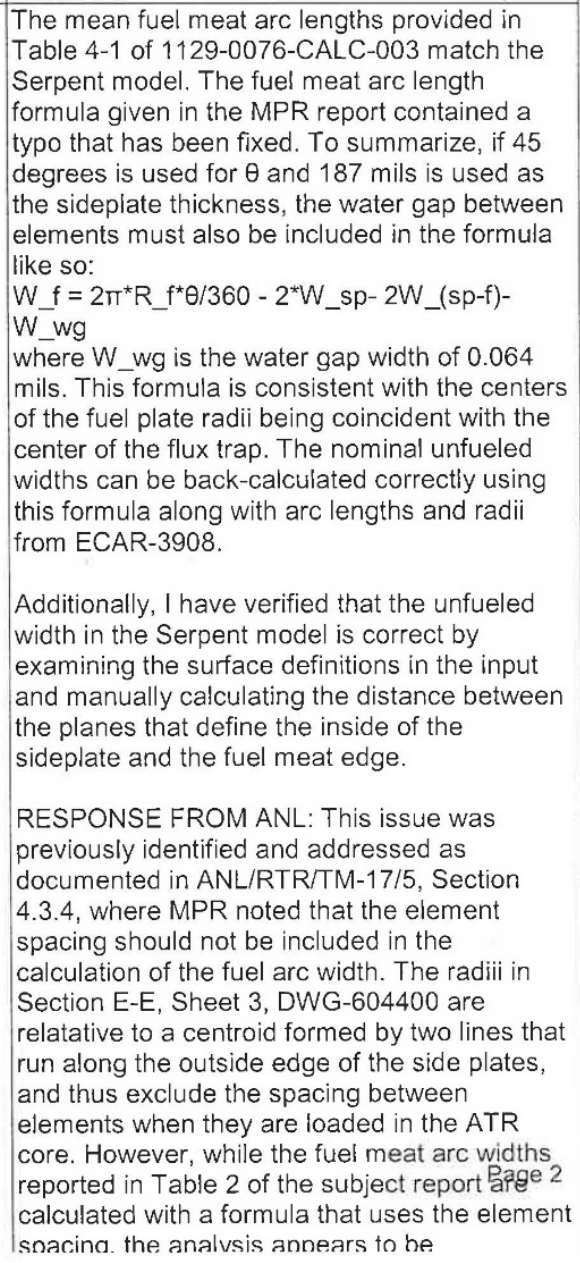 \\
\hline
\end{tabular}




\begin{tabular}{|c|c|c|c|c|c|c|c|}
\hline Technical Point of Contact: & Phone No: & Return Comments To: & MS: & E-Mail: & Comments Due By: & $\begin{array}{l}\text { Reviewer's Name/Discipline: } \\
\text { John Stillman/Neutronics \& Lara }\end{array}$ & $\begin{array}{l}\text { Phone No.: } \\
630-252-4277\end{array}$ \\
\hline \multicolumn{2}{|l|}{ Comments resolved by: } & \multicolumn{2}{|l|}{ Date: } & \multirow{2}{*}{\multicolumn{3}{|c|}{ Signature of reviewer accepting comment resolutions: }} & Date: \\
\hline \multicolumn{2}{|l|}{ Matt Johnson } & \multicolumn{2}{|c|}{ Unknown } & & & & $12 / 19 / 17$ \\
\hline
\end{tabular}

Comments, submitted within the scope of the review, should be resclved between feviewer and document owner, or ther agant. If an acceptable resoluton carnot ba nogatiated, tha reviewer may ascalate the issue to management for resolution.

\begin{tabular}{|c|c|c|c|c|}
\hline \multicolumn{3}{|c|}{ Document ID: ECAR-3909 } & Document Title: Results of ELF Mk 1A Conceptual Design Neutronics Analysis & \multirow{2}{*}{\begin{tabular}{l|l} 
Revision ID: & eCR No: \\
& Comment Resolution
\end{tabular}} \\
\hline Item No. & $\begin{array}{c}\text { Page } \\
\text { No }\end{array}$ & $\begin{array}{l}\text { Section or } \\
\text { Zone }\end{array}$ & Review Comment & \\
\hline 1 & 9 & 8.1 & $\begin{array}{l}\text { Typographical error near the bottom of the page. It is stated that "element } 5 \text { has a } \\
\text { history of " } 34-30 \text { ", meaning it occupied position } 34 \text { during P1 and position } 30 \text { during } \\
\text { P1." The last occurrence of "P1" in this sentence should be "P2". }\end{array}$ & $\begin{array}{l}\text { Sentence corrected to read " } . . . \text { and position } 30 \\
\text { during P2" } \\
\text { ANL RESPONSE: We accept this resolution. }\end{array}$ \\
\hline 2 & 10 & $\begin{array}{c}\text { Table 3, } \\
4\end{array}$ & $\begin{array}{l}\text { Typographical error. The EOC exposure is given in unites of MW. This should be } \\
\text { MWd. }\end{array}$ & $\begin{array}{l}\text { Units changed to MWd } \\
\text { ANL RESPONSE: We accept this resolution. }\end{array}$ \\
\hline & & & & \\
\hline & & & & \\
\hline & & & & \\
\hline & & & & \\
\hline & & & & \\
\hline & & & & \\
\hline & & & & \\
\hline & & & & \\
\hline & & & & \\
\hline & & & & \\
\hline & & & & \\
\hline
\end{tabular}




\begin{tabular}{|c|c|c|c|c|c|c|c|}
\hline Technical Point of Contact: & Phone No: & Return Comments To: & MS: & E-Mail: & Comments Due By: & $\begin{array}{l}\text { Reviewer's Name/Discipline: } \\
\text { John Stilmani/Neutronics \& Lara }\end{array}$ & \begin{tabular}{|l|} 
Phone No.: \\
630-252-4277
\end{tabular} \\
\hline \multicolumn{2}{|c|}{ Comments resolved by: } & \multicolumn{2}{|l|}{ Date: } & \multirow{2}{*}{\multicolumn{3}{|c|}{ Signature of reviewer accepting comment resolutions: }} & Date: \\
\hline \multicolumn{2}{|c|}{ Thomas Maddock } & \multicolumn{2}{|c|}{ Unknown } & & & & $18 / 17$ \\
\hline
\end{tabular}

Comments, sutmittes within the scope of the review, should be resched between reviewer and document owner, or thair agent. If an acceptable rosolution cannot be nogotated, the reviewer may escalate the issue to managerment for resolution

\begin{tabular}{|c|c|c|c|c|}
\hline \multicolumn{3}{|c|}{ Document ID: SPC-1694 } & $\begin{array}{l}\text { Document Title: Specification for Advanced Test Reactor Low Enriched Uranium (LEU) Fuel } \\
\text { Elements }\end{array}$ & \multirow{2}{*}{\begin{tabular}{|l|l|} 
Revision ID: & eCR No: \\
& Cornment Resolution \\
\end{tabular}} \\
\hline Item No. & $\begin{array}{l}\text { Page } \\
\text { No }\end{array}$ & $\begin{array}{l}\text { Section or } \\
\text { Zone }\end{array}$ & Review Comment & \\
\hline 1 & 19 & 3.3.1.1 & $\begin{array}{l}\text { It is stated that fuel bearing plates "shall be in compliance with Section } 3.1 \text { of this } \\
\text { specification." Section } 3.1 \text { of SPC-1694 specifies requirements for the fuel foil. } \\
\text { Should Section } 3.2 \text {, which specifies requirements for the fuel plates, also be included } \\
\text { in this statement? }\end{array}$ & $\begin{array}{l}\text { Changed to read "shall be in compliance with } \\
\text { Section } 3.1 \text { and } 3.2 \text { of this specification." } \\
\text { ANL RESPONSE: We accept the resolution. }\end{array}$ \\
\hline 2 & $33-36$ & 8 & $\begin{array}{l}\text { Recommend using the definitions in SPC-1635 (Rev. 8, dated 10/31/17). This would } \\
\text { be especially helfpful for the definitions of Diffusion Barrier Layer, Foil, Fuel Core, } \\
\text { Fuel Plate, and Fuel System. The term "Fuel Meat" is used in SPC-1694, but this is } \\
\text { not the typical term for monolithic fuels. }\end{array}$ & $\begin{array}{l}\text { The term "Fuel Meat" will be removed from the } \\
\text { definition list and other definitions will be } \\
\text { revised to be consistant with the latest version } \\
\text { of SPC-1635 } \\
\text { ANL RESPONSE: We accept the resolution. }\end{array}$ \\
\hline & & & & \\
\hline & & & & \\
\hline & & & & \\
\hline & & & & \\
\hline & & & 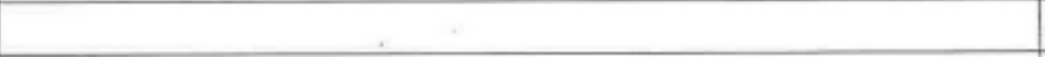 & \\
\hline & & & & \\
\hline & & & & \\
\hline & & & & \\
\hline & & & - & \\
\hline & & & & \\
\hline & & & & \\
\hline
\end{tabular}




\begin{tabular}{|c|c|c|c|c|c|c|c|}
\hline Technics Poimt of Contact: & Phone No:: & Refum Comments To: & MS: & E-Mail & Comments Due By: & \begin{tabular}{|l} 
Feviewer's Name/Discipline: \\
Nate Olcham Mecherical Engineering
\end{tabular} & \begin{tabular}{|r|} 
Phone $\mathrm{Na}:$ \\
$6-6338$
\end{tabular} \\
\hline \multicolumn{2}{|c|}{$\begin{array}{l}\text { Cormments resolved by: } \\
\text { Thomas Maddock }\end{array}$} & \multicolumn{2}{|c|}{$\begin{array}{l}\text { Date: } \\
\text { Unknown }\end{array}$} & \multicolumn{3}{|c|}{ Signofre of reviamer pacpepting comment resolutions: } & $\tan 25$ \\
\hline
\end{tabular}

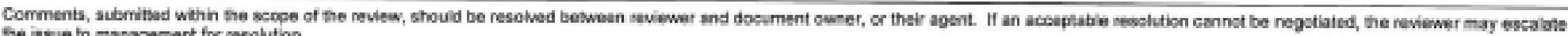
he issue to management for nesolution.

\begin{tabular}{|c|c|c|c|c|}
\hline \multicolumn{3}{|c|}{ Document ID: ECAR-3162 } & Documert Titer. ELF Conoept Struetural Evaluation & Revision ID: - \\
\hline Item No. & $\begin{array}{l}\text { Page } \\
\text { No }\end{array}$ & $\begin{array}{c}\text { Section or } \\
\text { Zone }\end{array}$ & Review Comment & Camment Resclution \\
\hline 1. & 825 & Weight & Dry weight is calculated at $41.3 \mathrm{lb} /$ and drawing says $37,3 \mathrm{lbf}$. & $\begin{array}{l}\text { A suggested change was added to the } \\
\text { document in EDMS to correct this error when } \\
\text { the document is revised next. A revision is } \\
\text { planned for } 2018 \text {. }\end{array}$ \\
\hline 2. & $\begin{array}{l}\text { B41- } \\
842\end{array}$ & Inem 32 & $\begin{array}{l}\text { Actual weld area is machined down to remove siots from side plates. I believe that } \\
\text { the model incorroctly has too much cross-sectional area in the weid region. }\end{array}$ & $\begin{array}{l}\text { A suggested change was added to the } \\
\text { document in EDMS to correct this error when } \\
\text { the document is revised next. A revision is } \\
\text { planned for } 2018 \text {. }\end{array}$ \\
\hline & & & & Changes to be made at revision 1 \\
\hline & & & & \\
\hline & & & & \\
\hline & & & . & 01/23/18. Suggestion D \\
\hline & & & & 23159,23160 and 23161 \\
\hline & & & & \\
\hline & & & & \\
\hline & & & & \\
\hline & & & & \\
\hline & & & & \\
\hline & & & & \\
\hline
\end{tabular}




\begin{tabular}{|c|c|c|c|c|c|c|c|}
\hline Technical Point of Contact: & Phone No: & Return Comments To: & MS: & E-Mail: & Comments Due By: & $\begin{array}{l}\text { Reviewer's Name/Discipline: } \\
\text { Nate Oldham Mechanical Engineering }\end{array}$ & $\begin{array}{r}\text { Phone No: } \\
6-6336 \\
\end{array}$ \\
\hline \multicolumn{2}{|c|}{$\begin{array}{l}\text { Comments resolved by: } \\
\text { Thomas Maddock }\end{array}$} & \multicolumn{2}{|c|}{$\begin{array}{l}\text { Date: } \\
\text { Unknown }\end{array}$} & \multicolumn{3}{|c|}{ Signature of reviewer gogepting comment resolutions: } & $18 \operatorname{Tan} 25$ \\
\hline
\end{tabular}

Comments, submitted within the soope of the review, should be resolved between reviewer and document owner, of their agent. If an acceptable resolution cannot be negotiated, the reviewer may escalate

\begin{tabular}{|c|c|c|c|c|}
\hline \multicolumn{3}{|c|}{ Document ID: 604400} & Document Title: ATR ELF Element Assembly & \multirow{2}{*}{\begin{tabular}{|c|c|} 
Revision ID: - & eCR No:: - \\
Comment Resolution
\end{tabular}} \\
\hline Item No. & $\begin{array}{l}\text { Page } \\
\text { No }\end{array}$ & \begin{tabular}{c|} 
Section or \\
Zone
\end{tabular} & Review Comment & \\
\hline 1. & 1 & $\begin{array}{c}\text { Weld } \\
\text { call-out }\end{array}$ & $\begin{array}{l}\text { Thsis drawing shows a one-sided weld. It seems more likely that this is a double } \\
\text { sided weld. }\end{array}$ & $\begin{array}{l}\text { Confirmed welds are actually one sided. No } \\
\text { change being made. }\end{array}$ \\
\hline 2. & 1 & Item 32 & Add UNS R60001 to item material description. & Change has been made \\
\hline 3. & All & All & $\begin{array}{l}\text { The Mark VII fuel element has been updated to Autodesk Inventor software. Suggest } \\
\text { converting this drawing from Autocad to Inventor to be consistent. }\end{array}$ & $\begin{array}{l}\text { This is going to be done in the near future. } \\
\text { Current drawing set is being revised one more } \\
\text { time. }\end{array}$ \\
\hline 4. & 2 & Zone C2 & $\begin{array}{l}\text { The } 4 X \text { on the tack weld and the } 2 X \text { on the viow along with the double-sided weld } \\
\text { symbol makes it seem like there is } 16 \text { welds. Suggest just removing the } 4 X \text { because } \\
\text { the tail description describes it best. }\end{array}$ & Change has been made \\
\hline 5. & 3 & Table 1 & $\begin{array}{l}\text { This table along with the plate detail describe inspection dimensions. I suggest } \\
\text { adding a table of nominal dimensions - i.e. radius, arc lengths, and fuel thickness - } \\
\text { so that it can be modeled correctly. }\end{array}$ & $\begin{array}{l}\text { No change is currently being made. This is } \\
\text { being considered for a planned drawing } \\
\text { revision in the near future. }\end{array}$ \\
\hline 6. & 3 & Zone D7 & Identify the tooling point. & Change has been made \\
\hline 7. & 3 & Zone B3 & Add section arrows to show where the view M section is applicable. & Change has been made \\
\hline 8. & 3 & Zone B1 & Suggest mentioning that fuel plate items are bonded per SPC-1694. & $\begin{array}{l}\text { Bonding lines were update to accurately show } \\
\text { how LEU fuel is made. }\end{array}$ \\
\hline 9. & 3 & Zone C1 & $\begin{array}{l}\text { View M shows the Zr interlayer on the ends of the fuel meat. This is inconsistent with } \\
\text { SPC-1694. }\end{array}$ & Zr was removed from the end of detail view. \\
\hline 10. & All & All & Misc. editorial comments provided per a redline markup of the drawing. & Other editorial comments were accepted. \\
\hline & & & & \\
\hline & & & & \\
\hline & & & & \\
\hline & & & & \\
\hline
\end{tabular}




\begin{tabular}{|l|l|c|l|l|l|l|}
\hline Technical Point of Contact: & Phone No.: & Return Comments To: & MS: & E-Mail: & Comments Due By: & $\begin{array}{l}\text { Reviewer's Name/Discipline: } \\
\text { Nolan Anderson/Thermalhydraulics }\end{array}$ \\
\hline $\begin{array}{l}\text { Comments resolved by: } \\
\text { Collin Clark }\end{array}$ & Date: & $\begin{array}{l}\text { Shone No: } \\
208 \text { 526-9323 }\end{array}$ \\
\hline
\end{tabular}

Comments, submitted within the scope of the review, should be resolved between reviewer and document owner, or their agent. If an acceptable resolution cannot be negotiated, the reviewer may escalate

\begin{tabular}{|c|c|c|c|c|}
\hline \multicolumn{3}{|c|}{$\begin{array}{l}\text { Document ID: } 1129-0076- \\
\text { CALC-006 }\end{array}$} & Document Title: ATR LEU Cycle R2 Analysis & $\begin{array}{l}\text { Revision ID: } 0 \\
\text { (preliminary) }\end{array}$ \\
\hline Item No. & $\begin{array}{l}\text { Page } \\
\text { No }\end{array}$ & \begin{tabular}{|l}
$\begin{array}{l}\text { Section or } \\
\text { Zone }\end{array}$ \\
\end{tabular} & Review Comment & Comment Resolution \\
\hline 1 & 18 & 7.1 .3 & $\begin{array}{l}\text { Figure } 7-6 \text { gives the trips which shut down two of the pumps. Is the shutdown of the } \\
\text { third pump automatic, or does an additional trip need to be added for the third pump? }\end{array}$ & $\begin{array}{l}\text { Trips } 455 \text { and } 456 \text { are time delay trips for PCPS } \\
\text { and are implemented for LOCA transients. Trip } \\
455 \text { completes the trip for pump } 145 \text { (PCP M-6) } \\
\text { and Trip } 456 \text { completes the trip for pump } 155 \\
\text { (PCP M-7) and } 165 \text { (PCP M- } 8 \text { ). Therefore, } \\
\text { these two trips alone accomplish the trip } \\
\text { function for all three PCPs during a LOCA. } \\
\text { In order to add clarity, an additional sentence is } \\
\text { added. }\end{array}$ \\
\hline 2 & 22,66 & $7.1 .5,9.4$ & $\begin{array}{l}\text { In speaking of the LOCP case the write up talks about } 2 \text { PCPs being active, but cycle } \\
\text { R2 has three active PCPs. It appears that the input is correct, but the write up should } \\
\text { be modified to indicate that } 3 \text { PCPs are active }\end{array}$ & $\begin{array}{l}\text { The write-up is modified to indicate that } 3 \text { PCPs } \\
\text { are active. }\end{array}$ \\
\hline 3 & 22 & 7.1 .5 & $\begin{array}{l}\text { Trip } 452 \text { displayed in Figure } 7-17 \text { is set to } 2.0 \text { in the input deck but is labelled as } 0.0 \\
\text { here. I believe the Trip in the write up is incorrect, but correct in the input deck. }\end{array}$ & $\begin{array}{l}\text { The write up is modified to indicated that trip } \\
452 \text { occurs at } 2.0 \text { seconds. }\end{array}$ \\
\hline & & & & \\
\hline & & & & \\
\hline & & & & \\
\hline & & & & \\
\hline & & & & \\
\hline & & & & \\
\hline
\end{tabular}


412.13

$04 / 14 / 2009$

Rev. 08
DOCUMENT MANAGEMENT REVIEW COMMENTS AND RESOLUTIONS
Tracking No:

(Optional)

\begin{tabular}{|c|c|c|c|c|c|c|c|}
\hline Technical Point of Contact: & Phone No.: & Return Comments To: & MS: & E-Mail: & Comments Due By: & \begin{tabular}{|l|} 
Reviewer's Name/Discipline: \\
Nolan Anderson/Thermalhydraulics
\end{tabular} & $\begin{array}{l}\text { Phone No.: } \\
208 \text { 526-9323 }\end{array}$ \\
\hline $\begin{array}{l}\text { Comments resolved by: } \\
\text { Collin Clark }\end{array}$ & & $\begin{array}{l}\text { Date: } \\
11 / 17 / 2 \\
\end{array}$ & & & iewer accepting cc & omment resolutions: & $2-14-17$ \\
\hline
\end{tabular}

Comments, submitted within the scope of the review, should be resolved between reviewer and document owner, or their agent. If an acceptable resolution cannot be negotiated, the reviewer may escalate

\begin{tabular}{|c|c|c|c|c|}
\hline \multicolumn{3}{|c|}{$\begin{array}{l}\text { Document ID: 1129-0076- } \\
\text { CALC-002 }\end{array}$} & Document Title: ATR LEU Cycle R1 Analysis & \begin{tabular}{|l|l|}
$\begin{array}{l}\text { Revision ID: } 0 \\
\text { (preliminary) }\end{array}$ & eCR No.: \\
\end{tabular} \\
\hline Item No. & $\begin{array}{l}\text { Page } \\
\text { No }\end{array}$ & $\begin{array}{c}\text { Section or } \\
\text { Zone }\end{array}$ & Review Comment & Comment Resolution \\
\hline & & & No comment & No edits made due to comments. \\
\hline & & & & \\
\hline & & & & \\
\hline & & & & \\
\hline & & & & \\
\hline & & & & \\
\hline & & & & \\
\hline & & & & \\
\hline & & & & \\
\hline & & & & \\
\hline & & & & \\
\hline & & & & \\
\hline & & & & \\
\hline & & & & \\
\hline & & & & \\
\hline & & & & \\
\hline
\end{tabular}




\begin{tabular}{|l|l|c|l|l|l|l|l|}
\hline Technical Point of Contact: & Phone No.: & Return Comments To: & MS: & E-Mail: & Comments Due By: & $\begin{array}{l}\text { Reviewer's Name/Discipline: } \\
\text { Nolan Anderson/Thermalhydraulics }\end{array}$ & $\begin{array}{l}\text { Phone No.: } \\
208526-9323\end{array}$ \\
\hline $\begin{array}{l}\text { Comments resolved by: } \\
\text { Raheem Rashid }\end{array}$ & Date: & November 20, 2017 & \multicolumn{3}{|c|}{ Signature of geviewer accepting comment resolutions: } \\
\hline
\end{tabular}

Comments, submitted within the scope of the review, should be resolved between reviewer and document owner, or their agent. If an acceptable resolution cannot be negotiated, the reviewer may escalate

\begin{tabular}{|c|c|c|c|c|}
\hline \multicolumn{3}{|c|}{$\begin{array}{l}\text { Document ID: 1129-0076- } \\
\text { CALC-003 }\end{array}$} & Document Title: Mark 1A ELF Thermal Hydraulic Inputs & Revision ID: 1 \\
\hline Item No. & $\begin{array}{l}\text { Page } \\
\text { No }\end{array}$ & $\begin{array}{l}\text { Section or } \\
\text { Zone }\end{array}$ & Review Comment & Comment Resolution \\
\hline 1 & 10 & 4.1 & $\begin{array}{l}\text { The thermal conductivity properties listed in Table 4-2 are generated with a } \\
\text { correlation given later in the document. This correlation is dependent on variable Fd } \\
\text { (fission density). The properties in the table were calculated with a fission density of } \\
0.0 \text {. Is this appropriate being that some of the fuel has already been irradiated? In } \\
\text { any case, a comment should be added indicating that the thermal conductivity } \\
\text { properties were calculated with } \mathrm{Fd}=0 \text {. }\end{array}$ & $\begin{array}{l}\text { A fission density of } 0 \text { is assumed for input to } \\
\text { the RELAP model. This is reasonable because } \\
\text { RELAP is used to model the bulk ATR system } \\
\text { response while ATR-SINDA is used to model } \\
\text { the detailed coolant channel and plate } \\
\text { behavior. Thus material property degradation } \\
\text { and fuel swelling are considered in the ATR- } \\
\text { SINDA model, but not in RELAP5. Assumption } \\
5 \text { was added to the calculation to clarify this } \\
\text { modeling assumption. }\end{array}$ \\
\hline 2 & 10 & 4.1 & $\begin{array}{l}\text { The values that I calculated for the volumetric heat capacity using the provided } \\
\text { correlations do not match the values in Table } 4-2 \text {. The differences are not huge, but I } \\
\text { calculated them for Fd }=0 \text { with the exact same correlations and I got different results. } \\
\text { This was not the case for the thermal conductivity. }\end{array}$ & $\begin{array}{l}\text { The values in Table } 4-2 \text { are calculated using a } \\
\text { constant U-10Mo density at room temperature. } \\
\text { This is done to maintain the mass of fuel } \\
\text { modeled in RELAP, which does not account for } \\
\text { changes in volume as a function in } \\
\text { temperature. A note will be added to the table } \\
\text { to clarify this. }\end{array}$ \\
\hline 3 & 20 & 5.6 & $\begin{array}{l}\text { Should add a note that the units that the correlations are converted to are necessary } \\
\text { for input to SINDA. }\end{array}$ & Agreed; note added. \\
\hline 4 & 20 & 5.6 & $\begin{array}{l}\text { Fd is listed as being fissions } / \mathrm{cm}^{\wedge} 3 \text {, but it is actually } 10^{\wedge} 21 \text { fissions } / \mathrm{cm}^{\wedge} 3 \text { to make the } \\
\text { units work. }\end{array}$ & Agreed; units for fission density are corrected. \\
\hline 5 & 20 & 5.6 & Equation for tswell, t0 should be in the numerator. & is corrected. \\
\hline 6 & 20 & 5.6 & $\begin{array}{l}\text { U10-Mo thermal conductivity equation converts } \mathrm{T} \text { from } \mathrm{F} \text { to } \mathrm{K} \text { by }(\mathrm{T}+459.67) / 1.8 \text {, but } \\
\text { materials. dat file uses } 273.15+(\mathrm{T}-32) / 1.8 \text { which is equivalent, but may cause } \\
\text { confusion. }\end{array}$ & $\begin{array}{l}\text { Agreed; temperature conversion is made } \\
\text { consistent between materials. dat and } \\
\text { calculation. }\end{array}$ \\
\hline 7 & 21 & 5.6 & $\begin{array}{l}\text { The units for Fd for the fuel blistering temperature correlation are different than used } \\
\text { otherwise. Here a value of }>1.5^{\star} 10^{\wedge} 21 \text { fissions } / \mathrm{cm}^{\wedge} 3 \text { is required. Should make units } \\
\text { of Fd consistent. }\end{array}$ & $\begin{array}{l}\text { A new variable } f d \text { has been introduced with } \\
\text { units of fissions/cm3 to avoid confusion with the } \\
\text { varibale } \mathrm{Fd} \text { with units of } \times 1021 \text { fissions/cm3. }\end{array}$ \\
\hline
\end{tabular}

Page 1 
412.13

$04 / 14 / 2009$

Rev. 08

Document ID: 1129-0076-

CALC-003

Item No.

\begin{tabular}{c|c}
$\begin{array}{c}\text { Page } \\
\text { No }\end{array}$ & $\begin{array}{c}\text { Section or } \\
\text { Zone }\end{array}$ \\
\hline
\end{tabular}

Document Title: Mark 1A ELF Thermal Hydraulic Inputs

5.6

Did not find the equation for Fuel Blistering Temperatu

fissions $/ \mathrm{cm}^{\wedge} 3$ in the Reference cited.

DOCUMENT MANAGEMENT

REVIEW COMMENTS AND RESOLUTIONS

Tracking No:

(Optional)

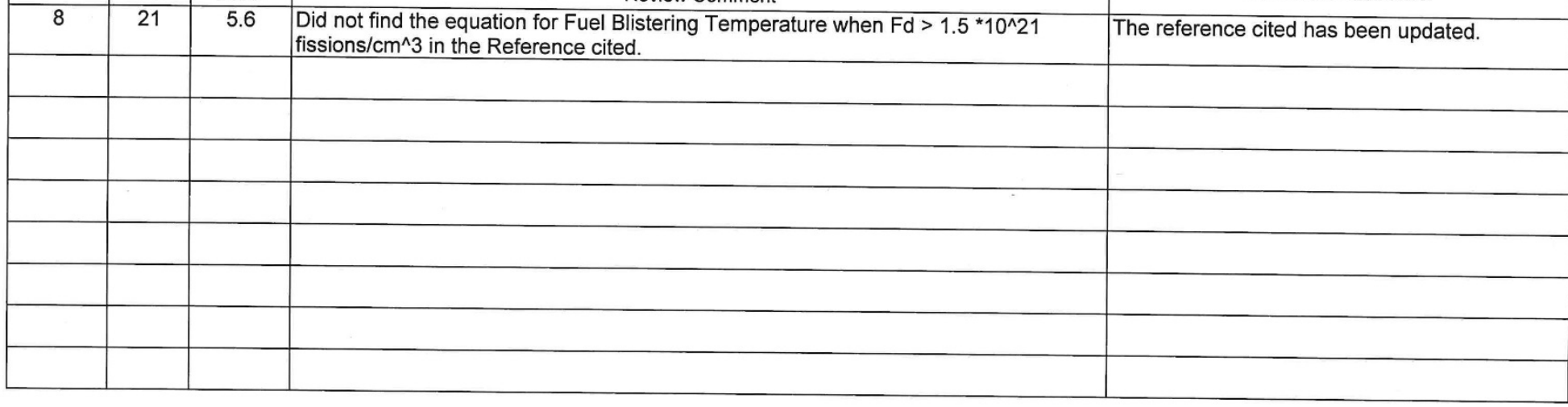




\begin{tabular}{|l|l|c|l|l|l|l|}
\hline Technical Point of Contact: & Phone No.: & Return Comments To: & MS: & $\begin{array}{l}\text { E-Mail: } \\
\text { hikaru.hiruta }\end{array}$ & $\begin{array}{l}\text { Comments Due By: } \\
\text { 11/09/2017 }\end{array}$ & $\begin{array}{l}\text { Reviewer's Name/Discipline: } \\
\text { Hikaru Hiruta }\end{array}$ \\
\hline $\begin{array}{l}\text { Comments resolved by: } \\
\text { Matt Johnson }\end{array}$ & Date: & Signature of revieywer accepting comment resolutions: \\
\hline
\end{tabular}

Comments, submitted within the scope of the review, should be resclved benween reviewer and document owner, or their agent. If an acceprable resolution cannot be negctiated, the reviawer may escalatte

\begin{tabular}{|c|c|c|c|c|}
\hline \multicolumn{3}{|c|}{ Document ID: ECAR-39C8 } & Document Title: Serpent Model Used in ELF Mk 1 A Conceptual Design Neutronic Analysis & \multirow{2}{*}{\begin{tabular}{|l|l|} 
Revision ID: & eCR No: \\
& Comment Resolution \\
\end{tabular}} \\
\hline Item No. & $\begin{array}{l}\text { Page } \\
\text { No }\end{array}$ & $\begin{array}{l}\text { Section or } \\
\text { Zone }\end{array}$ & Review Comment & \\
\hline 1 & 7 & 4 & $\begin{array}{l}\text { What does "ELF" stand for? "ELF" appears in the first time in the statement "The } \\
\text { dimension of the ELF Mk 1A element are taken ...". State a full name as "E___ } \\
\text { L_ F__ (ELF)". }\end{array}$ & Wording changed as recommended. \\
\hline 2 & 13 & & $\begin{array}{l}\text { The title of Table } 4 \text { would be better to change to "Burnable region volumes in each } \\
\text { axial level." }\end{array}$ & Title changed as recommended \\
\hline 3 & 34 & 8.6 .1 & $\begin{array}{l}\text { The first statement, "Serpent calculates reaction rates...... by tallying a fine-group } \\
\text { spectrum in each material.". Recommend to change to "Serpent calculates reaction } \\
\text { rates ... by a unified energy grid for all materials." and cite Serpent manual as a } \\
\text { reference. }\end{array}$ & $\begin{array}{l}\text { Changed the statement to: "Serpent calculates } \\
\text { the one-group cross sections needed for the } \\
\text { depletion calculation by tallying a fine-group } \\
\text { spectrum in each material and using this } \\
\text { spectrum to collapse the continuous energy } \\
\text { cross sections. The flux spectrum is calculated } \\
\text { using the problem's unionized energy grid } \\
\text { which contains about } 200,000 \text { points (see } \\
\text { Section } 8.6 .2 \text { for additional discussion of the } \\
\text { unionized energy grid). " }\end{array}$ \\
\hline 4 & 35 & & $\begin{array}{l}\text { In Table 17, values in last } 4 \text { rows are not REs, so it should be mentioned in the } \\
\text { footnote by putting marks }(*, 1) \text {, or etc) in these numbers. }\end{array}$ & $\begin{array}{l}\text { I split the table to show which quantities are } \\
\text { REs and which quantities are }+/ \text { - }\end{array}$ \\
\hline 5 & 39 & & $\begin{array}{l}\text { Is Figure } 9 \text { really showing the distribution of "peak" fission density? This sensitivity } \\
\text { study was performed without azimuthal levels, right? Then, it should be just fission } \\
\text { density instead of peak fission density? }\end{array}$ & $\begin{array}{l}\text { You are correct. Plot axis label and plot title } \\
\text { changed to reflect that it is the fission density. }\end{array}$ \\
\hline 6 & 39 & & $\begin{array}{l}\text { This is related to Item No. } 5 \text {. Is table } 19 \text { comparing the difference of peak fission } \\
\text { densities of 5-and 20-level cases which occur in the axial center of each plate or the } \\
\text { maximum difference of the axial distribution of the fission density? }\end{array}$ & $\begin{array}{l}\text { The table is comparing the peak which occurs } \\
\text { at the axial midplane. Added wording to section } \\
\text { 8.6.3.1" } \\
\text { "Results are shown in Table 21. The results are } \\
\text { presented as the percent difference in the peak } \\
\text { fission density (i.e. the fission density at the } \\
\text { core mid-plane) between the } 5 \text { level } \\
\text { discretization and the } 20 \text { level discretization." }\end{array}$ \\
\hline
\end{tabular}


412.13

$04 / 14 / 2009$

Rev. 08
DOCUMENT MANAGEMENT REVIEW COMMENTS AND RESOLUTIONS
Tracking No.

(Optional)

\begin{tabular}{|c|c|c|c|c|}
\hline \multicolumn{3}{|c|}{ Document ID: ECAR-3908 } & Document Title: Serpent Model Used in ELF Mk 1A Conceptual Design Neutronic Analysis & \multirow{2}{*}{\begin{tabular}{|l|l|} 
Revision ID: & eCR No:: \\
& Comment Resolution \\
\end{tabular}} \\
\hline Item No. & $\begin{array}{c}\text { Page } \\
\text { No }\end{array}$ & $\begin{array}{c}\text { Section or } \\
\text { Zone }\end{array}$ & Review Comment & \\
\hline 7 & 40 & & $\begin{array}{l}\text { Similarly, Is Table } 20 \text { showing the percent difference of the peak fission densities, } \\
\text { which occur in the azimuthal edge of plates? Please clarify. }\end{array}$ & $\begin{array}{l}\text { Adjusted and added the following: } \\
\text { "The effect on plate peak fission density at day } \\
112 \text { is shown Table } 22 \text {. The peak fission } \\
\text { density always occurs on either the left-most or } \\
\text { right-most region of the plate." }\end{array}$ \\
\hline 8 & 40 & & $\begin{array}{l}\text { One more thing about this azimuthal discretization study. Do both } 5 \text { and } 20 \\
\text { azimuthal-region cases have the same burnup zones ( } 5 \text { as stated in Section 8.2.1)? } \\
\text { This should also be stated clearly. }\end{array}$ & $\begin{array}{l}\text { Yes they do use the same burnup zones. I } \\
\text { have written, "Two cases are considered, the } \\
\text { first case has an azimuthal discretization } \\
\text { identical to production runs. The second case } \\
\text { has every plate divided into } 20 \text { equally sized } \\
\text { azimuthal regions. Both discretizations use the } \\
\text { plate material grouping as described in Table } \\
\text { 3." }\end{array}$ \\
\hline & & & & \\
\hline & & & & \\
\hline & & & & \\
\hline & & & & \\
\hline & & & & \\
\hline & & & & \\
\hline & & & & \\
\hline & & & & \\
\hline
\end{tabular}




\begin{tabular}{|c|c|c|c|c|c|c|c|}
\hline Technical Point of Contact: & Phone No.: & Return Comments To: & MS: & 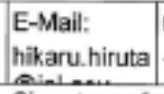 & $\begin{array}{l}\text { Comments Due By: } \\
11 / 09 / 2017\end{array}$ & $\begin{array}{l}\text { Reviewer's Name/Discipline: } \\
\text { Hikaru Hiruta }\end{array}$ & Phone No.: \\
\hline $\begin{array}{r}\text { Comments resolved by: } \\
\text { Matt Johnson }\end{array}$ & & $\begin{array}{l}\text { Date: } \\
\text { Unk: }\end{array}$ & & Signature of $r$ & revigwer accepting $\rho$ & imment resolutions: & \\
\hline
\end{tabular}

Comments, subenitted within the scope of the review, should be resolved between feviewer and document owner, or their agent. If an acceptable resolution cannot be negotiated, the reviewer may escalate the issue to managerment for resolution.

\begin{tabular}{|c|c|c|c|c|}
\hline \multicolumn{3}{|c|}{ Document ID: ECAR-3909 } & Document Titte: Results of ELF Mk 1A Conceptual Design Neutronic Analysis & Revision ID: \\
\hline item No. & $\begin{array}{l}\text { Page } \\
\text { No }\end{array}$ & $\begin{array}{c}\text { Section or } \\
\text { Zone }\end{array}$ & Review Comment & Comment Resolution \\
\hline 1 & 8 & 8.1 & $\begin{array}{l}\text { In the statement of the first paragraph of Sectipn } 8.1 \text { " "The first two cycles, called } \\
\text { Cycle P1 (P1) and Cycle P2 (P2), are used to generate a library of spent fuel } \\
\text { elements." "Spent fuer" sounded like the one that has removed from the reactor and } \\
\text { never come back. It might be better to change to "... to generate a library of once and } \\
\text { twice bumed fuel elements, respectively." }\end{array}$ & Changed as recommended \\
\hline 2 & 8 & 8.1 & $\begin{array}{l}\text { Similarly in the next statement, ".,. a mixture of fresh and spent fuel shuffled in a } \\
\text { realistic manner." Change "spent fuel" to "burned fuer". }\end{array}$ & Changed as recommended \\
\hline 3 & 9 & 8.1 & $\begin{array}{l}\text { In the sentense of the last paragraph, "..." } 34-30 " \text {, meaning it occupied position } 34 \\
\text { during P1 and position } 30 \text { during P1". The second P1 should be P2. }\end{array}$ & Changed \\
\hline 4 & & 8.1 & Will it be possible to add core map to show where positions $1-40$ are? & Added a core map as Figure 1 \\
\hline 5 & 32 & 8.2 .5 & $\begin{array}{l}\text { In Section } 8.2 .5 \text {, what are the conditions (fuel temp., mod. temp., and mod. density) } \\
\text { for the "reference" state for the evaluation of reactivities. They should be stated in the } \\
\text { paragraph. }\end{array}$ & $\begin{array}{l}\text { Added the sentence, "Nominal fuel } \\
\text { temperature, moderator temperature, and } \\
\text { moderator pressure is given in Section } \\
8.2 .2 \text { of ECAR-3908." }\end{array}$ \\
\hline 6 & $50-58$ & & $\begin{array}{l}\text { In Figures } 9-17, \text { titles of these figures should also indicate what they are. For } \\
\text { instance, instead of "Figure } 9 \text { : Plate } 19 \text { of element zero at P1 day 0 (left) and P1 day } \\
3 \text { right", it is better to be "Figure 9: Distributions of power and fission densities over } \\
\text { Plate } 19 \text { of element zero at...." }\end{array}$ & Changed as recommended \\
\hline
\end{tabular}




\begin{tabular}{|c|c|c|c|c|}
\hline \multicolumn{3}{|c|}{ Document ID: ECAR-3909 } & Document Title: Results of ELF Mk $1 \mathrm{~A}$ Conceptual Design Neutronic Analysis & Revision ID: \\
\hline Item No. & $\begin{array}{l}\text { Page } \\
\text { No }\end{array}$ & $\begin{array}{c}\text { Section or } \\
\text { Zone }\end{array}$ & Review Comment & Comment Resolution \\
\hline 7 & & & $\begin{array}{l}\text { This is just question. In reality, will HEU->LEU transition occur by completely } \\
\text { removing all HEU plates and loading all fresh LEU to startup like Cycle P1 in the } \\
\text { report, or gradually replacing HEU fuel elements with fresh LEU fuel (if possible)? In } \\
\text { case of Cycle P1, were there any indications of higher peak-to-average power ratio } \\
\text { compared to Cycles R1 or R2? If so, are there any safety issues because of higher } \\
\text { peak-to-average ratio? }\end{array}$ & $\begin{array}{l}\text { The intent of this design is to never operate at full } \\
\text { power with an all fresh core. A fully fresh core would } \\
\text { require burnable poison and this would affect the } \\
\text { power profiles and peaking in some manner, } \\
\text { although the magnitude of the effects would depend } \\
\text { on the solution used. The P1 cycle used fixed Hf } \\
\text { rods in the small B, A, and H positions. ECAR-2547 } \\
\text { used Gd poisons in the large B positions to suppress } \\
\text { reactivity. ECAR-2546 did not report the effects on } \\
\text { fuel power peaking. Gd is a much blacker poison, } \\
\text { but the large B positions are further away from the } \\
\text { fuel than the small B and A positions. I'm not sure off } \\
\text { the top of my head whether Gd poisons in the large } \\
\text { B would be worse (w.r.t. power peaking) than the Hf } \\
\text { shims in multitudinous locations. } \\
\text { For a simple comparison of peaking consider the } \\
\text { following: The highest power density seen in the } \\
\text { reactor during P1 was } 59.9 \text { [kW/cm³] and the highest } \\
\text { heat flux was } 660[\text { [W/cm²]. The highest power } \\
\text { density seen during R2 was } 57.8\left[\mathrm{~kW} / \mathrm{cm}{ }^{3}\right] \text { and the } \\
\text { highest heat flux was } 717 \text { W/cm²]. The peak power } \\
\text { density (which occurs in plate } 19 \text { ) is higher in the all- } \\
\text { fresh poisoned core, but the peak heat flux (which } \\
\text { occurs in plate } 15 \text { usually) is lower. How much of this } \\
\text { difference is due to the poisons and how much is } \\
\text { due to differences in OSCC rotation is not known at } \\
\text { this time. A more rigorous analysis is needed to } \\
\text { prove anything definitively, but it appears that } \\
\text { peaking in an all-fresh core isn't significantly worse } \\
\text { than peaking in an all-fresh lobe. } \\
\text { We will operate with an all-fresh core during post- } \\
\text { CIC physics testing once we have fully converted } \\
\text { and probably once before we start the HEU->LEU } \\
\text { transition process, but this is only for low power } \\
\text { operation. }\end{array}$ \\
\hline & & & & \\
\hline & & & & \\
\hline
\end{tabular}




\begin{tabular}{|c|c|c|c|c|c|c|c|}
\hline $\begin{array}{l}\text { Technical Point of Contact: } \\
\text { Matthew P. Johnson }\end{array}$ & $\begin{array}{l}\text { Phone No.: } \\
208-526-2786\end{array}$ & Return Comments To: & MS: & E-Mail: & Comments Due By: & $\begin{array}{l}\text { Reviewer's Name/Discipline: } \\
\text { Anne K. McCartin }\end{array}$ & $\begin{array}{l}\text { Phone No: } \\
\text { 200-533-4461 }\end{array}$ \\
\hline \multicolumn{2}{|c|}{$\begin{array}{l}\text { Comments resolved by: } \\
\text { Matt Johnson }\end{array}$} & \multicolumn{2}{|c|}{$\begin{array}{l}\text { Date: } \\
\text { Unknown }\end{array}$} & \multicolumn{3}{|c|}{ Signaturg of reviewer accepting comment resclutions: } & $14 \mid 17$ \\
\hline
\end{tabular}

Ccmments, submited whinin the scope of the review, should be resolved between reviewer and document owner, or their agent If an acceptable resolution cannot be negotiated, the reviewer mey ascalate
the issue to management for resolution.

\begin{tabular}{|l|l|l|l}
\hline Document ID: ECAR-3909 Document Title: Results of ELF Mk 1 A Conceptual Design Neutronic Analysis
\end{tabular}

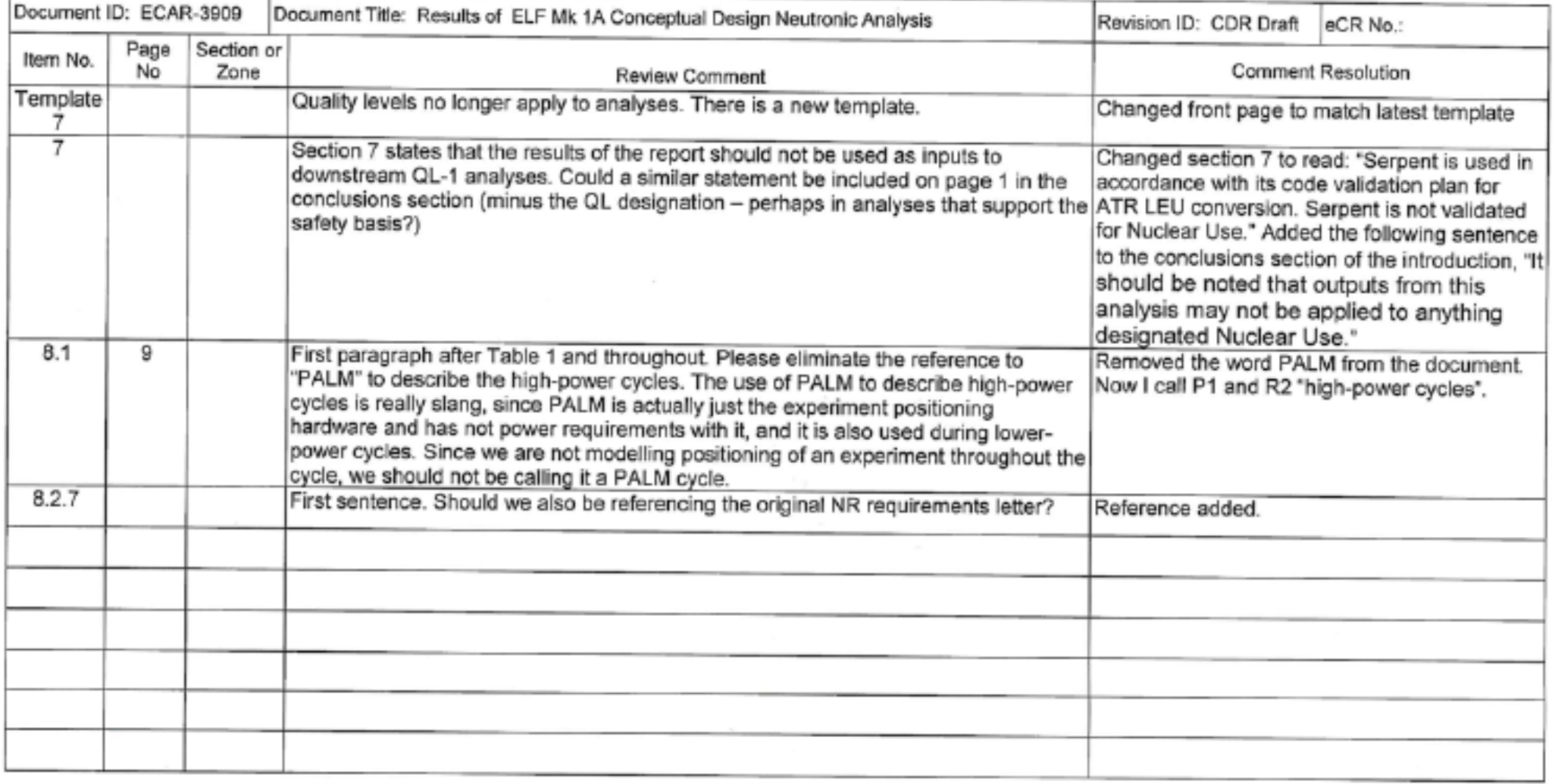




\begin{tabular}{|c|c|c|c|c|c|c|c|}
\hline $\begin{array}{l}\text { Technical Point of Contact: } \\
\text { Matthew P. Johnson }\end{array}$ & $\begin{array}{l}\text { Phone No.: } \\
208-526-2786\end{array}$ & Return Comments To: & MS: & E-Mail: & Comments Due By: & $\begin{array}{l}\text { Reviewer's Name/Discipline: } \\
\text { Anne K. MoCartin } \\
\end{array}$ & $\begin{array}{l}\text { Phone No: } \\
\text { 208-533-4461 }\end{array}$ \\
\hline $\begin{array}{l}\text { Comments resolved by: } \\
\text { Matt Johnson }\end{array}$ & & $\begin{array}{l}\text { Date: } \\
\text { Unk }\end{array}$ & & Signat: & eviewer accepting & nment resolutions: & $\{14 \mid 17$ \\
\hline
\end{tabular}

Comments, submilted within the scope of the review, should be resolved between reviewer and document owner, or their egent If an acoptable resolution cannol be negotiated, the reviewer may escalate

\begin{tabular}{|c|c|c|c|c|}
\hline \multicolumn{3}{|c|}{ Document ID: ECAR-3908 } & Document Title: Serpent Model Used in ELF Mk 1 A Conceptual Design Neutronic Analysis & Revision ID: CDR Draft \\
\hline Item No. & $\begin{array}{l}\text { Page } \\
\text { No }\end{array}$ & $\begin{array}{l}\text { Section or } \\
\text { Zone }\end{array}$ & Review Comment & Comment Resolution \\
\hline $\begin{array}{c}\text { Template } \\
7\end{array}$ & & & Quality levels no longer apply to analyses. There is a new template. & $\begin{array}{l}\text { Changed the front page to match the new } \\
\text { template }\end{array}$ \\
\hline 9 & 1 & & $\begin{array}{l}\text { Section } 7 \text { states that the results of the report should not be used as inputs to } \\
\text { downstream QL-1 analyses. Could a similar statement be included on page } 1 \text { in the } \\
\text { conclusions section (minus the QL designation - perhaps in analyses that support the } \\
\text { safety basis?) }\end{array}$ & $\begin{array}{l}\text { Changed section } 7 \text { to read: 'Serpent is } \\
\text { validated for work related to ATR LEU } \\
\text { conversion. Error! Referenco sourse not found. } \\
\text { Serpent is not validated for Nuclear Use." } \\
\text { Added the following sentence to the } \\
\text { conclusions section of the introduction, "It } \\
\text { should be noted that outputs from this } \\
\text { analysis may not be applied to anything } \\
\text { designated Nuclear Use." }\end{array}$ \\
\hline 8.2 .1 & 12 & & $\begin{array}{l}\text { Editorial. A few lines above Table } 3 \text {. Sentence reads "and } 15-19 \text { are treated as } \\
\text { uniquely..." Change uniquely to unique. }\end{array}$ & $\begin{array}{l}\text { Tweaked the wording in that section. That } \\
\text { sentence now reads "and } 15-19 \text { are treated } \\
\text { individually..." }\end{array}$ \\
\hline & & & & \\
\hline & & & & \\
\hline & & & & \\
\hline & & & & \\
\hline & & & & \\
\hline & & & & \\
\hline
\end{tabular}




\begin{tabular}{|l|l|l|l|l|l|l|}
\hline $\begin{array}{l}\text { Technical Point of Contact } \\
\text { Joe Palmer }\end{array}$ & Phone No:: & Retum Comments To: & MS: & E-Mail: & $\begin{array}{l}\text { Comments Due By: } \\
11 / 9 / 2017\end{array}$ & $\begin{array}{l}\text { Reviewer's Name/Discipline: } \\
\text { Jeff Sherman/Nuclear Safety }\end{array}$ \\
\hline $\begin{array}{l}\text { Comments resolved by: } \\
\text { T. Maddock, M. Johnson, MPR, }\end{array}$ & $\begin{array}{l}\text { Date: } \\
\text { Misc }\end{array}$ & $\begin{array}{l}\text { Signature of reviewer accepting comment resolutions: } \\
\text { 6-7324 }\end{array}$ \\
\hline
\end{tabular}

Comments, submitted within the scope of the review, should be resolved between reviewer and document owner, or their egent If an acoeptable resolution cannot be negotiated, the reviewer may escalate

\begin{tabular}{|c|c|c|c|c|}
\hline \multicolumn{3}{|c|}{ Document ID: } & Document Titte: ATR LEU Conversion Fuel Element - Conceptual Design & Revision ID: \\
\hline Item No. & $\begin{array}{l}\text { Page } \\
\text { No }\end{array}$ & $\begin{array}{l}\text { Section or } \\
\text { Zone }\end{array}$ & Review Comment & Comment Resolution \\
\hline 1 & 7 & sect. 5 & ECAR-3908, editorial, fix "the that" & removed "the" \\
\hline 2 & & Table 1 & ECAR-3908, fuel regions row, clarify "universe $1000^{\prime}$ meaning & $\begin{array}{l}\text { Removed reference to universe } 1000 \text { since it } \\
\text { didn't really fit in the table well. Changed the } \\
\text { description to read, "input file that pieces the } 40 \\
\text { fuel elements into a serpentine configuration". } \\
\text { Also added a footnote to Table } 8 \text { explaining } \\
\text { that universes } 1-40 \text { contain fuel elements } 1-40 \text {. } \\
\text { There is only one other reference to a universe } \\
\text { found Section } 8.4 .8 \text {, but this one is explaining } \\
\text { an example line of Serpent input so I think it is } \\
\text { self-contained enough that it doesn't require } \\
\text { additional clarification }\end{array}$ \\
\hline 3 & & Table 3 & ECAR-3909, EOC Exposure column header should be MWD (also in Table 4) & Column header changed as recommended \\
\hline 4 & & $\begin{array}{l}\text { sect. } \\
8.2 .1\end{array}$ & $\begin{array}{l}\text { ECAR-3909, Cycle R1 is } 56 \text { day length; why not } 60 \text { to more closely match ATR } \\
\text { capability? }\end{array}$ & $\begin{array}{l}56 \text { days comes from the NR functional } \\
\text { requirements for cycle length, specifically } 56 \\
\text { days at } 120 \mathrm{MW} \text {. }\end{array}$ \\
\hline 5 & & $\begin{array}{l}\text { sect. } \\
8.2 .2\end{array}$ & ECAR-3909, correct "that the an" in 1"t paragraph & Changed to "that an" \\
\hline 6 & & sect. & ECAR-3909, "were' should be "where" in $1^{\text {st }}$ paragraph & Changed \\
\hline 7 & 4 & & $\begin{array}{l}\text { ECAR-3162, Recommendation is to test a full size element to validate assumption } \\
\text { about Zr bond heat transfer as part of the fuel development effort. Is there a plan to } \\
\text { do this test prior to putting ET-1 in ATR? }\end{array}$ & $\begin{array}{l}\text { This recommendation will be considered during } \\
\text { the final design. Currently there are no plans to } \\
\text { conduct the test. }\end{array}$ \\
\hline & & & & \\
\hline & & & & \\
\hline & & & & \\
\hline
\end{tabular}


DOCUMENT MANAGEMENT

\begin{tabular}{|l|l|l|l|l|l|l|}
\hline Technical Point of Contact: & Phone No.: & Return Comments To: & MS: & E-Mail: & Comments Due By: & $\begin{array}{l}\text { Roviewer's Name/Discipline: } \\
\text { J. o. Brower }\end{array}$ \\
\hline $\begin{array}{l}\text { Comments resolved by. } \\
\text { T. Maddock, M. Johnson, MPR, }\end{array}$ & Date: Misc & Signatuveofreviewer accepting comment resolutions: \\
\hline
\end{tabular}

Ccrnments, submitied within the scope of the review, should be resolved between reviewer and document bwhor, or their agent. If an accepteble resolution cannok be negotiated, the reviewer may escalate

\begin{tabular}{|c|c|c|c|c|}
\hline \multicolumn{3}{|c|}{ Docurnent ID: multiple } & Document Tite: ATR LEU Converion Fuel Element & Revision ID: \\
\hline Item No. & $\begin{array}{l}\text { Page } \\
\text { No }\end{array}$ & $\begin{array}{c}\text { Soction or } \\
\text { Zone }\end{array}$ & Review Comment & Comment Resolution \\
\hline $\begin{array}{l}\text { PLN- } \\
5391\end{array}$ & 5 of 10 & 1 & First paragraph, fourth line, typo, missing "and" between "conditions" and "select". & $\begin{array}{l}\text { PLN-5391 is not being reviewed as part of the } \\
\text { conceptual design review. If a revision is made } \\
\text { to this document the typo will be fxed. }\end{array}$ \\
\hline $\begin{array}{l}\text { PLN- } \\
5381\end{array}$ & $\begin{array}{c}10 \text { of } \\
10\end{array}$ & 7 & Table at bottom of page, why aren't the document numbers included in the table? & $\begin{array}{l}\text { PLN-5391 is not being reviewed as part of the } \\
\text { conceptual design review. The plan was } \\
\text { created before the documents wore produced. } \\
\text { The document numbers weren't included } \\
\text { because they weren't available at the time. }\end{array}$ \\
\hline FOR-317 & 8 of 8 & $\begin{array}{c}\text { Referenc } \\
\text { es }\end{array}$ & $\begin{array}{l}\text { [11] Why is INL Drawing 035658, "ATR Fuel Element Mark VI Assembly" included as } \\
\text { a reference? Mark Vi ATR fuel elements weren't fabricated after the mid-1970"s. The } \\
\text { current ATR Mark VII Fuel Element drawing is } 405400 \text {, Rev. } 20 \text {. }\end{array}$ & $\begin{array}{l}\text { FOR-317 is not being reviewed as part of the } \\
\text { conceptual design review and was not written } \\
\text { by the ATR conversion team. }\end{array}$ \\
\hline
\end{tabular}




\begin{tabular}{|c|c|c|c|c|c|}
\hline \multicolumn{3}{|c|}{ Document ID: } & Document Title: ATR LEU Converion Fuel Element & Revision ID: & eCR No.: \\
\hline Item No. & $\begin{array}{l}\text { Page } \\
\text { No }\end{array}$ & $\begin{array}{c}\text { Section or } \\
\text { Zone }\end{array}$ & Review Comment & \multicolumn{2}{|c|}{ Comment Resolution } \\
\hline $\begin{array}{l}\text { SPC- } \\
1694\end{array}$ & All & All & $\begin{array}{l}\text { The following is a brief summary of the most recent changes in SPC-1635 Rev. } 8 \text {, } \\
\text { which should also be incorporated into SPC-1694: } \\
\text { - The definition of "fuel meat" was eliminated, as this is a term appropriate for } \\
\text { dispersion fuel, not monolithic fuel. The term "fuel meat" was replaced with either } \\
\text { "fuel foil" or "fuel core," as appropriate. } \\
\text { - The definition of "fuel core" was revised. "Fuel Core. The uranium bearing region of } \\
\text { each fuel plate." } \\
\text { - The definition of "foil" was revised. "Foil. A thin product of metal alloy containing } \\
\text { fissionable material with or without the diffusion barrier layers." } \\
\text { - SPC-1635, } 1.05 \text { Definitions, U-Mo Alloy, "coupons" will never be used to fabricate } \\
\text { U-Mo fuel cores in the future. The definition of "coupon" and the usage of the word } \\
\text { "Coupon" in the definition of U-Mo Alloy can be deleted from SPC-1635. The use of } \\
\text { "coupon" remains unchanged in TEV-2009. } \\
\text { - The definition of "cladding" was revised to specify that it is an aluminum alloy rather } \\
\text { than aluminum. The term "clad" was changed to "cladding," particularly in SPC-1635. } \\
\text { - SPC-1635, Section 4.05.A, will be revised as follows: "A. The as received cladding } \\
\text { shall be aluminum (see def.) alloy } 6061 \text { (per ASTM B209)." The Aluminum } \\
\text { Association prefix of "AA" will be used in front of the } 6061 \text { aluminum alloy } \\
\text { designation. No heat treatment suffix will be specified, since the } 6061 \text { aluminum alloy } \\
\text { will change form during the HIP process. Other uses of UNS A96061 or AA6061 used } \\
\text { throughout SPC-1635, FOR-158, and TEV-2009 are not required to be changed. }\end{array}$ & $\begin{array}{l}\text { Definitions h } \\
\text { specification } \\
\text { and SPC-16 } \\
\text { design. }\end{array}$ & $\begin{array}{l}\text { updated. Material } \\
\text { esolved when drawings } \\
\text { ised during the final }\end{array}$ \\
\hline $\begin{array}{l}\text { SPC- } \\
1694\end{array}$ & $\begin{array}{c}11 \text { of } \\
39\end{array}$ & Figure 1 & $\begin{array}{l}\text { Figure 1, Schematic diagram showing the cross section of a fuel plate will be } \\
\text { corrected to show "AA6061 Cladding" and "U-Mo (Fuel Core)". Barry Rabin revised } \\
\text { the image component labels. }\end{array}$ & $\begin{array}{l}\text { Materaial sp } \\
\text { the final desi }\end{array}$ & $\begin{array}{l}\text { will be resolved during } \\
\text { s. }\end{array}$ \\
\hline $\begin{array}{l}\text { SPC- } \\
1694\end{array}$ & All & All & References to LEU Fuel Plate Specification SPC-1635. SPC-1635 & No change & \\
\hline $\begin{array}{l}\text { SPC- } \\
1694\end{array}$ & \begin{tabular}{|c|}
$19 \& 20$ \\
of 39 \\
\end{tabular} & 3.3 .1 & Materials are listed on the drawings in the material list. & $\begin{array}{l}\text { This paragra } \\
\text { materials are }\end{array}$ & $\begin{array}{l}\text { tten to explain } \\
\text { e drawing. }\end{array}$ \\
\hline $\begin{array}{l}\text { SPC- } \\
1694\end{array}$ & $\begin{array}{c}30 \text { of } \\
39\end{array}$ & 5.8 .1 & DO NOT DELETE "BLISTER TEST." & No action rec & \\
\hline $\begin{array}{l}\text { Dwg } \\
604400\end{array}$ & 1 of 3 & C-8 & $\begin{array}{l}\text { INSPECTION ENVELOPE, Change " } 2 \times 1.303 " \text { to " } 2 \text { X } 1.330 " \text { ". Older versions of this } \\
\text { detail on drawing } 035658 \text { included a Note } 10 \text {. "Final assembly shall fit within } \\
\text { inspection envelope without interference at any point (the top } 3 \text { inches and side plate } \\
\text { pads excepted.)" The pads should fit within the inspection envelope. }\end{array}$ & $\begin{array}{l}\text { The dimensi } \\
\text { revised to inc } \\
\text { process. }\end{array}$ & $\begin{array}{l}\text { nged and the note was } \\
\text { ads in the inspection }\end{array}$ \\
\hline $\begin{array}{l}\text { Dwg } \\
604400\end{array}$ & 1 of 3 & $\begin{array}{c}\text { New } \\
\text { Note } 22\end{array}$ & $\begin{array}{l}\text { Note 22. As cast, radius dimensions on upper and lower adapters, that are not } \\
\text { machined during fabrication, are reference dimensions established by the casting. } \\
\text { These are not critical dimensions and shall not be measured. }\end{array}$ & $\begin{array}{l}\text { This note wil } \\
\text { planned for t }\end{array}$ & $\begin{array}{l}\text { ded in a future revision } \\
\text { nt drawing. }\end{array}$ \\
\hline
\end{tabular}




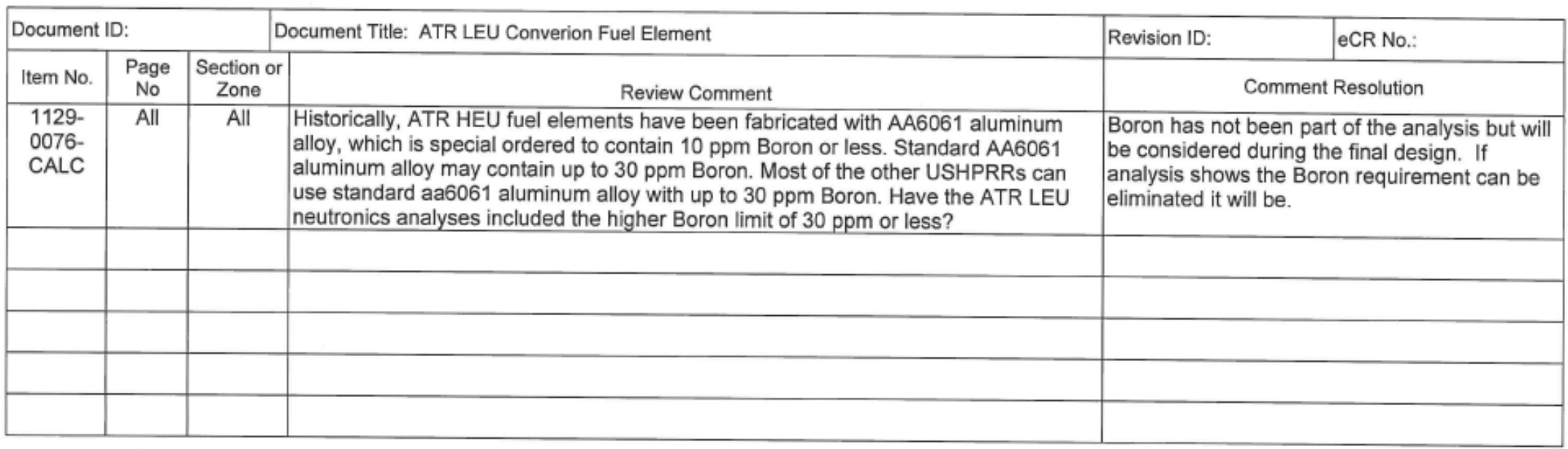

